\title{
Co-administration of paroxetine and pravastatin causes deregulation of glucose homeostasis in diabetic rats via enhanced paroxetine exposure
}

\author{
Feng LI, Mian ZHANG, Dan XU, Can LIU, Ze-yu ZHONG, Ling-ling JIA, Meng-yue HU, Yang YANG, Li LIU*, Xiao-dong LIU* \\ Key Laboratory of Drug Metabolism and Pharmacokinetics, China Pharmaceutical University, Nanjing 210009, China
}

\begin{abstract}
Aim: Clinical evidence shows that co-administration of pravastatin and paroxetine deregulates glucose homeostasis in diabetic patients. The aim of this study was to verify this phenomenon in diabetic rats and to elucidate the underlying mechanisms.

Methods: Diabetes mellitus was induced in male SD rats by a high-fat diet combined with a low-dose streptozotocin injection. The rats were orally administered paroxetine $(10 \mathrm{mg} / \mathrm{kg})$ and pravastatin $(10 \mathrm{mg} / \mathrm{d})$ or both the drugs daily for $28 \mathrm{~d}$. The pharmacokinetics of paroxetine and pravastatin were examined on $\mathrm{d} 1$ and $\mathrm{d} 28$. Biochemical parameters including serum insulin, glucose and lipids were monitored during the treatments. An insulin-secreting cell line (INS-1) was used for measuring insulin secretion.

Results: In diabetic rats, co-administration of paroxetine and pravastatin markedly increased the concentrations of both the drugs compared with administration of each drug alone. Furthermore, co-administration severely impaired glucose homeostasis in diabetic rats, as demonstrated by significantly increased serum glucose level, decreased serum and pancreatic insulin levels, and decreased pancreatic Insulin-2 mRNA and tryptophan hydroxylase-1 (Tph-1) mRNA levels. Treatment of INS-1 cells with paroxetine (5 and 10 $\mu \mathrm{mol} / \mathrm{L})$ significantly inhibited insulin secretion, decreased the intracellular insulin, 5-HT, Insulin-2 mRNA and Tph-1 mRNA levels. Treatment of the cells with pravastatin $(10 \mu \mathrm{mol} / \mathrm{L})$ significantly stimulated insulin secretion, which was weakened by co-treatment with paroxetine.

Conclusion: Paroxetine inhibits insulin secretion at least via decreasing intracellular 5-HT and insulin biosynthesis. The deregulation of glucose homeostasis by co-administration of paroxetine and pravastatin in diabetic rats can be attributed to enhanced paroxetine exposure.
\end{abstract}

Keywords: diabetes mellitus; paroxetine, pravastatin; drug-drug interaction; pharmacokinetics; insulin; 5-HT; tryptophan hydroxylase

Acta Pharmacologica Sinica (2014) 35: 792-805; doi: 10.1038/aps.2014.24

\section{Introduction}

Diabetes mellitus is often accompanied by depression and hypercholesterolemia. Hypercholesterolemia is thought to promote the development of atherosclerotic complications, thus lowering LDL-cholesterol is of vital importance in reducing cardiovascular risk in diabetes mellitus ${ }^{[1]}$. Statins, including pravastatin are frequently administered to diabetic patients for this purpose. Pravastatin prevents the onset of diabetes via lowering lipids, improving endothelial function, and ameliorating insulin resistance ${ }^{[2-4]}$. Enhanced insulin secretion by pravastatin via the organic anion transporter polypeptide transporter 2 (Oatp2) may be another reason for

\footnotetext{
* To whom correspondence should be addressed.

E-mail liulee@yeah.net (Li LIU); xdliu@cpu.edu.cn (Xiao-dong LIU)

Received 2014-02-06 Accepted 2014-03-21
}

its ability to prevent diabetes onset ${ }^{[5]}$.

Depression aggravates diabetic patients' outcomes ${ }^{[6,7]}$ due to impairment of insulin secretion ${ }^{[8,9]}$. Antidepressants such as selective serotonin reuptake inhibitors (SSRIs), including paroxetine, are commonly used in diabetic patients. Paroxetine improved glucose metabolism and insulin sensitivity via alleviating depression $^{[10,11]}$, although antidepressant use that was associated with disturbances in glucose homeostasis has been reported $^{[12,13]}$.

It is reasonable that SSRIs and statins are coadministered to diabetes patients, and pravastatin and paroxetine are the most widely prescribed drugs in these classes. However, multiple reports have demonstrated that comedication with pravastatin and paroxetine can increase the risk of elevated blood glucose levels in diabetic patients ${ }^{[14-16]}$, although neither pravastatin nor paroxetine alone have shown an effect on glucose levels. The real mechanism leading to the adverse drug reaction 
remains unclear.

Paroxetine is metabolized in the liver mainly by CYP2D6 ${ }^{[17]}$. Pravastatin is mainly excreted via the bile in an unmetabolized form $^{[18,19]}$. Hepatic uptake was determined to be the rate-limiting step in pravastatin clearance in humans via OATP1B1 ${ }^{[20]}$. Pravastatin was also reported to inhibit CYP2D6 activity ${ }^{[21,22]}$, indicating that interaction between paroxetine and pravastatin could alter the pharmacokinetic behaviors of paroxetine and pravastatin, and in turn affect their pharmacodynamic or toxic effects.

The aims of this study were as follows: first, to verify the deregulation of glucose homeostasis by comedication of paroxetine and pravastatin in diabetic rats; second, to investigate the pharmacokinetic behavior of paroxetine and pravastatin in diabetic rats with and without coadministration; third, to document the effects of paroxetine, pravastatin and their coadministration on insulin secretion from an insulin-secreting cell line (INS-1 cells). This study was expected to clarify the possible mechanisms leading to the deregulation of glucose homeostasis by coadministration of paroxetine and pravastatin during the diabetic state.

\section{Materials and methods Materials}

Pravastatin sodium, rosuvastatin calcium and paroxetine hydrochloride were from the National Institute for the Control of Pharmaceutical and Biological Products (Beijing, China). Streptozotocin (STZ), serotonin hydrochloride (5-HT), glucose6-phosphate, glucose-6-phosphate dehydrogenase (Type V) and $\beta$-nicotinamide adenine dinucleotide phosphate (NADP) were from Sigma Chemical Co (St Louis, MO, USA). Normal laboratory rodent chow and high-fat chow were from Jiangsu Xietong Organism Co, Ltd (Nanjing, China).

\section{Animals and treatment}

Male Sprague-Dawley rats $(100 \pm 20 \mathrm{~g})$ were supplied by SIPPR/BK Experimental Animal Co Ltd (Shanghai, China, 2008001628590). The rats were housed in a controlled animal facility at a temperature of $22 \pm 2{ }^{\circ} \mathrm{C}$ and a relative humidity of $50 \% \pm 10 \%$ with a $12-\mathrm{h}$ light/dark cycle. The experiments were carried out in accordance with the guidelines on the Care and Use of Animals developed by the National Advisory Committee for Laboratory Animal Research. The number of rats was kept as low as possible and the suffering of animals was minimized. The animal project was approved by the Animal Ethics Committee of China Pharmaceutical University.

Diabetic (DM) rats were induced by the combination of a high-fat diet and low-dose STZ injection according to a previously described method ${ }^{[23,24]}$. Briefly, high-fat diet (HFD) rats and DM rats were both fed with a high-fat diet that consisted of $15 \%$ lard $(w / w), 5 \%$ sesame oil, $20 \%$ sucrose, $2.5 \%$ cholesterol and $57.5 \%$ normal chow. The normal control (CON) rats were fed with normal chow. After 4 weeks of dietary manipulation, DM rats received STZ (35 mg/ kg in pH 4.5 citrate buffer) intraperitoneally. Both HFD and CON rats received the vehicle. On d 7 post-STZ injection, the fasting serum glu- cose levels were measured and the oral glucose tolerance test (OGTT) was performed: rats were fasted for $6 \mathrm{~h}$ followed by an oral dose of glucose $(2 \mathrm{~g} / \mathrm{kg})$ and serum glucose and insulin levels were determined at 0 (baseline), 30, 60, and $120 \mathrm{~min}$ after glucose administration. Rats with fasting serum glucose levels in excess of $11.1 \mathrm{mmol} / \mathrm{L}$ were considered to be DM rats and used for the following experiments.

DM rats received oral pravastatin $\left(10 \mathrm{mg} \cdot \mathrm{kg}^{-1} \cdot \mathrm{d}^{-1}, \mathrm{DM}-\mathrm{PR}\right)$, paroxetine $\left(10 \mathrm{mg} \cdot \mathrm{kg}^{-1} \cdot \mathrm{d}^{-1}, \mathrm{DM}-\mathrm{PA}\right)$ or comedication with both pravastatin and paroxetine (DM-CO) for $28 \mathrm{~d}$. The dose of pravastatin in rats was established in a prior report ${ }^{[25]}$, so we chose $10 \mathrm{mg} / \mathrm{kg}$ as our treatment dose of pravastatin. Similarly, we chose $10 \mathrm{mg} / \mathrm{kg}$ as the treatment dose of paroxetine $^{[26]}$. DM control rats, CON rats and HFD rats only received vehicle. Food intake and body weight were monitored once a week. Biochemical parameters in serum were measured and the OGTT was performed at a designed time during treatment. On d 29 of treatment, these rats were sacrificed under ether anesthesia and serum samples were obtained for assessing the biochemical parameters. The pancreas was removed for assaying the levels of insulin, 5-HT, Insulin-2 mRNA and tryptophan hydroxylase-1 (Tph-1) mRNA. The liver was removed for preparing hepatic microsomes and assessing the levels of target gene mRNA.

\section{Pharmacokinetics of pravastatin and paroxetine in diabetic rats}

Another batch of DM rats, fasted overnight, was randomly divided into four groups. Group 1 and group 2 were treated as DM-PR and DM-PA rats, respectively. Group 3 and group 4 were treated as DM-CO rats. The experimental rats were dosed as described above. On d 1 and 28 of the dosing regimen, blood samples $(0.25 \mathrm{~mL})$ from group 1 and group 3 rats for pharmacokinetics were collected under light ether anesthesia via the oculi chorioideae vein at 5, 15, 30, 45, 90, 120, and $240 \mathrm{~min}$ following pravastatin dosing. Blood samples $(0.25$ $\mathrm{mL}$ ) from group 2 and group 4 rats for pharmacokinetics were collected at $0.25,0.75,1.5,2,4,6,8,12$, and 24 h following paroxetine dosing. After each 3-4 samplings, approximately an equal amount of $0.9 \%$ saline was given to the experimental rats via the tail vein to compensate for blood loss. Plasma samples were obtained by centrifugation. Plasma concentrations of pravastatin and paroxetine were measured using LC-MS ${ }^{[27]}$ and HPLC ${ }^{[28]}$ methods, respectively. Pharmacokinetic parameters were individually estimated using noncompartmental analysis with Phenix WinNonlin 6.1 (Pharsight, St Louis, MO, USA).

\section{Insulin secretion from INS-1 cells and intracellular 5-HT levels}

INS-1 cells, from the American Type Culture Collection (Manassas, VA, USA), were seeded in 24-well plates at a density of $3 \times 10^{5}$ cells/well in RPMI-1640 medium supplemented with $10 \%(v / v)$ fetal bovine serum, $10 \mathrm{mmol} / \mathrm{L}$ HEPES, 2 $\mathrm{mmol} / \mathrm{L}$ glutamine, $1 \mathrm{mmol} / \mathrm{L}$ pyruvate, $50 \mu \mathrm{mol} / \mathrm{L}$ mercaptoethanol, $100 \mathrm{U} / \mathrm{mL}$ penicillin, and $0.1 \mathrm{mg} / \mathrm{mL}$ streptomycin in a $5 \% \mathrm{CO}_{2}$ atmosphere at $37^{\circ} \mathrm{C}$.

When the cells grew to $70 \%$ confluence, the cells were incu- 
bated with fresh medium containing different concentrations of pravastatin, paroxetine and 5-HT for $24 \mathrm{~h}$. The cultured cells were washed twice with a Krebs-Ringer Bicarbonate HEPES buffer (KRBH) containing glucose (11.1 or $2.8 \mathrm{mmol} / \mathrm{L})$ and were pre-incubated at $37^{\circ} \mathrm{C}$ for $20 \mathrm{~min}$ in $\mathrm{KRBH}$. Then, the cells were incubated with $\mathrm{KRBH}$ containing the experimental agents and glucose (11.1 or $2.8 \mathrm{mmol} / \mathrm{L})$ for $2 \mathrm{~h}$. The supernatant was collected for assessing insulin secretion ${ }^{[29,30]}$. The cells were collected for assaying intracellular insulin and 5-HT levels. The effect of tropisetron on inhibition of insulin secretion from INS-1 cells by 5-HT and paroxetine were also investigated. The protein content of the cells was determined using the Bradford protein assay. The cell viability was also measured using the MTT assay. No damage to the cells was found with any of these agents, within the tested concentration ranges.

\section{Metabolism of paroxetine in hepatic microsomes}

Hepatic microsomes of rats were prepared according to the methods described previously ${ }^{[23,31]}$. Paroxetine metabolism in microsomes was investigated using the substrate depletion approach described by Obach ${ }^{[32]}$. Paroxetine $(5 \mu \mathrm{mol} / \mathrm{L})$ was incubated with microsomes $(0.5 \mathrm{mg} / \mathrm{mL})$ in phosphate buffer (PBS, pH 7.4) for $5 \mathrm{~min}$. The reaction was initiated by adding $40 \mu \mathrm{L}$ of an NADPH-generating mixture $(0.5 \mathrm{mmol} / \mathrm{L}$ NADP, $10 \mathrm{mmol} / \mathrm{L}$ glucose-6-phosphate, $5 \mathrm{U} / \mathrm{mL}$ glucose-6-phosphate dehydrogenase, and $5 \mathrm{mmol} / \mathrm{L} \mathrm{MgCl}_{2}$ in a final volume of $200 \mu \mathrm{L}$ ) and terminated by adding $600 \mu \mathrm{L}$ of ice-cold methanol at $0,5,10,20,30,45$, and $60 \mathrm{~min}$. The amount of remaining paroxetine was measured. The area under the paroxetine concentration-time curve $\left(\mathrm{AUC}_{0-60}\right)$ was calculated using the linear trapezoidal rule. Clearance of hepatic microsomes was defined as the final volumexinitial paroxetine levels $/ \mathrm{AUC}_{0-60}$.

The time-dependent inhibitory effect of pravastatin on paroxetine metabolism in microsomes of DM rats was investigated. The NADPH-generating mixture and microsomes were pre-incubated at $37^{\circ} \mathrm{C}$ for $5 \mathrm{~min}$, then different concentrations of pravastatin were added to the mixture and incubated for 0,15 , and $30 \mathrm{~min}$, respectively, after which $40 \mu \mathrm{L}$ of the above mixture was transferred to another reaction system containing paroxetine $(5 \mu \mathrm{mol} / \mathrm{L})$ and a fresh NADPH-generating mixture in $200 \mu \mathrm{L}$ and incubated for $20 \mathrm{~min}$. The amount of remaining paroxetine was measured.

\section{Pravastatin and paroxetine uptake and paroxetine metabolism in hepatocytes}

Primary rat hepatocytes were isolated according to a technique described previously ${ }^{[33,34]}$. The isolated hepatocytes, suspended in DMEM plating media supplemented with 5\% $(v / v)$ fetal bovine serum, $1 \mu \mathrm{mol} / \mathrm{L}$ dexamethasone, $4 \mu \mathrm{g} / \mathrm{mL}$ insulin, $50 \mathrm{U} / \mathrm{mL}$ penicillin and $0.05 \mathrm{mg} / \mathrm{mL}$ streptomycin, were seeded in 24-well plates at a density of $1 \times 10^{5}$ cells/well in $500 \mu \mathrm{L}$. Following a 4 -h incubation in a $5 \% \mathrm{CO}_{2}$ atmosphere at $37^{\circ} \mathrm{C}$, the incubated hepatocytes were rinsed twice with prewarmed PBS and used for the following experiments.

Paroxetine $(0.5,5$, and $25 \mu \mathrm{mol} / \mathrm{L})$ and rifampicin $(20$ $\mu \mathrm{mol} / \mathrm{L})$ were added to the incubated hepatocytes, respectively, and pre-incubated for $5 \mathrm{~min}$. The uptake reaction was initiated by adding $500 \mu \mathrm{L}$ of $25 \mu \mathrm{mol} / \mathrm{L}$ pravastatin and stopped by washing with ice-cold PBS three times at 10, 30, 60, and $120 \mathrm{~s}$. The uptake of pravastatin by the hepatocytes was measured. The effect of pravastatin on the uptake of paroxetine by hepatocytes was determined as described above.

The effect of pravastatin on paroxetine metabolism in hepatocytes of DM rats was simultaneously investigated. Different levels of pravastatin were added to the isolated hepatocytes and incubated for $5 \mathrm{~min}$. The reaction was initiated by adding $500 \mu \mathrm{L}$ of $0.2 \mu \mathrm{mol} / \mathrm{L}$ paroxetine and stopped by adding 500 $\mu \mathrm{L}$ of ice-cold methanol at $0.5,1,2,4$, and $6 \mathrm{~h}$ following incubation. The amount of remaining paroxetine in the reaction mixture was measured and the clearance of paroxetine in the hepatocytes was calculated.

\section{Quantitative real-time PCR}

The levels of Insulin-2, Tph-1, Cyp2D1, Cyp2D2, Oatp2, and the multidrug resistance-associated protein (Mrp2) mRNA were measured using QT-PCR. Total RNA from the cells and tissues was extracted according to the method provided by TRIzol reagent kit (Gibco, BRL, USA) according to the manufacturer's instructions. QT-PCR was performed using the listed primers (Table 1) and the SYBR green PCR Master Mix on the ABI Prism 7500 Sequence Detection System (Applied Biosystems, Life Technologies Co, USA) with the following profile: denaturing at $95^{\circ} \mathrm{C}$ for $2 \mathrm{~min}, 95^{\circ} \mathrm{C}$ for $5 \mathrm{~s}$, and $60^{\circ} \mathrm{C}$ for $35 \mathrm{~s}$ for 40 cycles. The expression of each gene was normalized to the amount of $\beta$-actin mRNA.

Table 1. The primers of target gene mRNA in QT-PCR.

\begin{tabular}{lll}
\hline Gene & \multicolumn{1}{c}{ Forward } & \multicolumn{1}{c}{ Reverse } \\
\hline Insulin-2 & 5'-ccctgcccaggctttgtca-3' & 5'-gtgtgtagaagaatccacgctcc-3' \\
Tph-1 & 5'-tgcgacatcaaccgagaaag-3' & 5'-caagggacagtctcctaacatc-3' \\
Oatp2 & 5'-gattggacttctgttggcttct-3' & 5'-gtgtatctgtgggagtatggt-3' \\
Mrp2 & 5'-cacggtcatcaccatcgctcac-3' & 5'-agttcttcaggactgccatactcg-3' \\
Cyp2D1 & 5'-tggacctcagtaacatgcca-3' & 5'-gatgcaaggatcacaccttg-3' \\
Cyp2D2 & 5'-tgagtggcgagagcagag-3' & 5'-cgagcataaacaagggagg-3' \\
B-actin & 5'-gggaaatcgtgcgtgacatt-3' & 5'-gcggcagtggccatctc-3'
\end{tabular}

\section{Drug assays}

Concentrations of pravastatin were determined using a Shimadzu LCMS-2020 system. Rosuvastatin in a volume of $10 \mu \mathrm{L}$ $(1 \mu \mathrm{g} / \mathrm{mL}$, internal standard) and $1 \mathrm{~mL}$ of $n$-butanol saturated with water were added to each of the $100 \mu \mathrm{L}$ samples. This mixture was shaken for $10 \mathrm{~min}$ and centrifuged at $8000 \times \mathrm{g}$ for $10 \mathrm{~min}$. The organic layer was transferred and evaporated to dryness in a vacuum evaporator (Thermo, Waltham, MA, USA). The residue was reconstituted in $100 \mu \mathrm{L}$ of methanol. An aliquot of $5 \mu \mathrm{L}$ was injected into the LC-MS system. Separation was performed at $40^{\circ} \mathrm{C}$ on a Waters Symmetry C18 column $(5.0 \mu \mathrm{m}, 2.1 \mathrm{~mm} \times 150 \mathrm{~mm})$. The mobile phase was 
composed of acetonitrile with $0.1 \%$ acetic acid $(45: 55, v / v)$ at a flow rate of $0.2 \mathrm{~mL} / \mathrm{min}$. The mass spectrometer was operated in the negative electrospray ionization mode using selective ion monitoring data acquisition: pravastatin $[\mathrm{M}-\mathrm{H}]^{-} \mathrm{m} / \mathrm{z} 423$, rosuvastatin $[\mathrm{M}-\mathrm{H}]^{-} m / z$ 480. Mass spectrometric conditions were optimized as follows: Heat Block: $350^{\circ} \mathrm{C}$; DL Temperature: $270^{\circ} \mathrm{C}$; Drying Gas: $10.0 \mathrm{~L} / \mathrm{min}$; Nebulizing: $1.5 \mathrm{~L} / \mathrm{min}$; Interface Voltage: $-4.5 \mathrm{kV}$. The recovery was larger than $85 \%$ and the relative standard deviations of intra-day and inter-day were lower than $15 \%$. The linear range of pravastatin in the plasma was 2-100 ng/mL. The lowest limit of quantification of pravastatin in the plasma was $2 \mathrm{ng} / \mathrm{mL}$.

Concentrations of paroxetine were determined using a Shimadzu HPLC system. $10 \mu \mathrm{L}$ of $\mathrm{NaOH}(1 \mathrm{~mol} / \mathrm{L})$ and $1 \mathrm{~mL}$ chloroform were added to each $100 \mu \mathrm{L}$ sample for the analysis of paroxetine. This mixture was shaken for $10 \mathrm{~min}$ and centrifuged at $8000 \times g$ for $10 \mathrm{~min}$. The organic layer was transferred and evaporated to dryness under a stream of nitrogen gas in a water-bath at $40^{\circ} \mathrm{C}$. The residue was reconstituted in 100 $\mu \mathrm{L}$ of mobile phase and $20 \mu \mathrm{L}$ was injected into the HPLC system after centrifugation at $16000 \times g$ for $10 \mathrm{~min}$. Separation was performed at $40^{\circ} \mathrm{C}$ on a Waters Symmetry C18 column $(5.0 \mu \mathrm{m}, 4.6 \mathrm{~mm} \times 150 \mathrm{~mm})$. The mobile phase was composed of acetonitrile with $5 \mathrm{mmol} / \mathrm{L}$ sodium dihydrogen phosphate $(28: 72, v / v)$ at a flow rate of $1 \mathrm{~mL} / \mathrm{min}$. The concentration of paroxetine was measured with a fluorescence detector (RF10AXL) set at an excitation wavelength of $295 \mathrm{~nm}$ and an emission wavelength of $350 \mathrm{~nm}$. The recovery was larger than $85 \%$ and the relative standard deviations of intra-day and inter-day were lower than $15 \%$. The linear range of paroxetine in the plasma was $2.5-500 \mathrm{ng} / \mathrm{mL}$. The lowest limit of quantification of paroxetine in the plasma was $2.5 \mathrm{ng} / \mathrm{mL}$.

Concentrations of 5-HT in the biological fluids were determined using a Shimadzu HPLC system. $100 \mu \mathrm{L}$ of $10 \%$ perchloric acid was added to each $100 \mu \mathrm{L}$ sample. This mixture was shaken for $10 \mathrm{~min}$ and centrifuged at $16000 \times g$ for $10 \mathrm{~min}$. $20 \mu \mathrm{L}$ of the supernatant was injected into the HPLC system. Separation was performed at $40^{\circ} \mathrm{C}$ on a Waters Symmetry C18 column $(5.0 \mu \mathrm{m}, 4.6 \mathrm{~mm} \times 150 \mathrm{~mm})$. The mobile phase was composed of methanol with $50 \mathrm{mmol} / \mathrm{L}$ potassium dihydrogen phosphate $(5: 95, v / v)$ at a flow rate of $1 \mathrm{~mL} / \mathrm{min}$. The concentration of 5-HT was measured with a fluorescence detector (RF-10AXL) set at an excitation wavelength of $278 \mathrm{~nm}$ and an emission wavelength of $338 \mathrm{~nm}$. The recovery was larger than $85 \%$ and the relative standard deviations of intra-day and inter-day were lower than 15\%. The linear range of 5-HT in the biological fluid was $1-500 \mathrm{ng} / \mathrm{mL}$. The lowest limit of quantification of 5-HT in the biological fluid was $1 \mathrm{ng} / \mathrm{mL}$.

\section{Statistical analysis}

All results are displayed as mean \pm standard error (SEM). Significant differences among groups were evaluated by one-way of analysis of variance (ANOVA). Differences between groups were estimated using a Student-Newman-Keuls multiple comparison post hoc test if needed. A nonparametric test was also used when necessary. A $P$-value of less than 0.05 was regarded as statistically significant.

\section{Results}

\section{Establishment of the diabetic rat model}

A suite of biochemical parameters (Table 2) was measured in CON rats, HFD rats and DM rats on $\mathrm{d} 7$ after the injection with STZ. Higher fasting glucose, triglyceride, and total cholesterol and lower body weight were observed in DM rats. The DM rats possessed typical diabetic symptoms such as polyphagia, polyuria, polydipsia and high HOMA-IR. Data from the OGTT showed that DM rats displayed higher postprandial glucose concentrations (Table 2) compared with CON rats and HFD rats. The postprandial insulin concentrations showed a trend toward increasing in DM rats, although no statistical significance was observed (Table 2). These indexes were similar to the pathophysiological state of diabetes, indicating that the DM rats may qualify as diabetic models.

\section{Effects of pravastatin, paroxetine and their comedication on biochemical parameters in the serum of diabetic rats}

Glucose, insulin, total cholesterol and triglyceride levels in the serum of diabetic rats treated with pravastatin, paroxetine and

Table 2. Physiological and biochemical characteristics in CON, HFD, and DM rats. Data represent the mean \pm SEM of $6-7$ rats. ${ }^{c} P<0.01$ vs CON rats. ${ }^{\mathrm{e}} P<0.05,{ }^{\mathrm{f}} P<0.01$ vs HFD rats.

\section{Parameter}

Initial body weight (g)

Final body weight (g)

Serum glucose $(\mathrm{mmol} / \mathrm{L})$

Serum triglyceride $(\mathrm{mmol} / \mathrm{L})$

Serum total cholesterol ( $\mathrm{mmol} / \mathrm{L})$

Serum insulin (mIU/L)

HOMA-IR

AUC of serum glucose in OGTT ( $\mathrm{mmol} \cdot \mathrm{h} / \mathrm{L})$

AUC of serum insulin in OGTT (mIU.h/L)
CON

$110.33 \pm 3.32$
$388.83 \pm 3.64$
$7.29 \pm 0.18$
$1.73 \pm 0.10$
$1.85 \pm 0.12$
$42.47 \pm 4.45$
$13.33 \pm 1.38$
$13.81 \pm 0.29$
$123.02 \pm 8.78$

HFD

$110.33 \pm 2.65$
$355.33 \pm 17.24$
$7.36 \pm 0.24$
$2.06 \pm 0.12^{\circ}$
$2.83 \pm 0.19^{\circ}$
$46.50 \pm 4.12$
$15.07 \pm 1.53$
$16.28 \pm 0.31$
$141.81 \pm 13.63$

DM

$109.50 \pm 1.65$
$308.75 \pm 7.81^{\text {ce }}$
$24.29 \pm 1.19^{\text {cf }}$
$2.48 \pm 0.22^{\text {ce }}$
$5.11 \pm 0.43^{\text {cf }}$
$44.91 \pm 6.90$
$47.40 \pm 5.65^{\text {cf }}$
$52.39 \pm 1.27^{\text {cf }}$
$132.83 \pm 14.74$

Glucose was measured by a glucose test kit (Jiancheng Biotech, Nanjing, China). Insulin was measured by iodine ${ }^{125}$ I] insulin radioimmunoassay kit (BNIBT Co, Beijing, China). Total cholesterol and triglyceride were measured by test kits (BHKT Clinical Reagent Co, Beijing, China). 
both drugs combined were monitored (Figure 1). The results showed that both paroxetine alone and when coadministered with pravastatin worsened glucose homeostasis, as verified by an increase in fasting serum glucose concentrations (Figure 1A) and a decrease in fasting serum insulin concentrations (Figure 1B). The deterioration of glucose homeostasis by coadministration of pravastatin and paroxetine was stronger than that by paroxetine alone. Compared with DM-PA rats, the DM-CO rats exhibited lower fasting serum insulin levels and higher fasting serum glucose concentrations. DM-PA rats also showed a trend toward a decrease in fasting serum insulin levels. Although the postprandial glucose levels did not change in the OGTT, the serum glucose levels before glucose loading still increased in DM-CO rats (Figure 2A and 2C), which was in accordance with the fasting serum glucose levels. Compared with DM rats, DM-CO rats displayed significantly decreased postprandial insulin levels and a decrease in the AUC for insulin in the OGTT (Figure 2B and 2D), especially on d 28 following treatment (Figure 2D, $P=0.0226$ for AUC). All these results verified the deterioration of glucose homeostasis by coadministration of paroxetine and pravastatin in diabetic rats.

It was consistent with our expectations that DM rats increased serum total cholesterol and serum triglyceride levels (Table 2). Pravastatin, a hypolipidemic drug, reversed the increased total cholesterol levels induced by diabetes. Paroxetine treatment did not affect the total cholesterol levels in diabetic rats, but coadministration of paroxetine and pravastatin tended to weaken the cholesterol-lowering effects of pravastatin (Figure 1C). However, the three treatments did not affect the increased serum triglyceride levels induced by diabetes (Figure 1D).
Effects of pravastatin, paroxetine and their comedication on serum 5-HT, pancreatic insulin and 5-HT in diabetic rats

The levels of serum 5-HT in experimental rats were measured on d 29 following treatment. Compared with CON rats, DM rats also showed significantly lower serum 5-HT levels (Figure 3A, $P=0.0480$ ). Paroxetine slightly increased serum 5-HT concentration and the increase was enhanced by coadministration of pravastatin, although pravastatin itself tended to decrease 5-HT concentration.

Insulin and 5-HT levels in pancreas of experimental rats were measured on d 29 following treatment. The results showed that pravastatin treatment showed a trend toward reversing the decreased pancreatic insulin levels induced by DM (Figure 3B), but coadministration of pravastatin and paroxetine might further strengthen the decrease in pancreatic insulin levels induced by diabetes $(P=0.0249)$. This result was different from the finding in serum that the pancreatic 5-HT levels were not altered in the experimental rats (Figure 3C).

The levels of Insulin-2 and Tph-1 mRNA in the pancreas of experimental rats were also assessed. As expected from the decrease in pancreatic and serum insulin levels, diabetes significantly suppressed expression of Insulin-2 mRNA (Figure $3 \mathrm{D}, P=0.0003)$. Paroxetine treatment showed a trend toward exacerbating the impaired expression of Insulin-2 induced by diabetes, and the diabetes-induced impairment was further enhanced by coadministration of pravastatin $(P=0.0253$, DM-CO versus DM rats). Although diabetes did not affect the expression of pancreatic Tph-1 mRNA, comedication of pravastatin and paroxetine significantly suppressed the expression of pancreatic Tph-1 mRNA, leading to a $25 \%$ decrease in the DM rats (Figure 3E, $P=0.0149$ ).
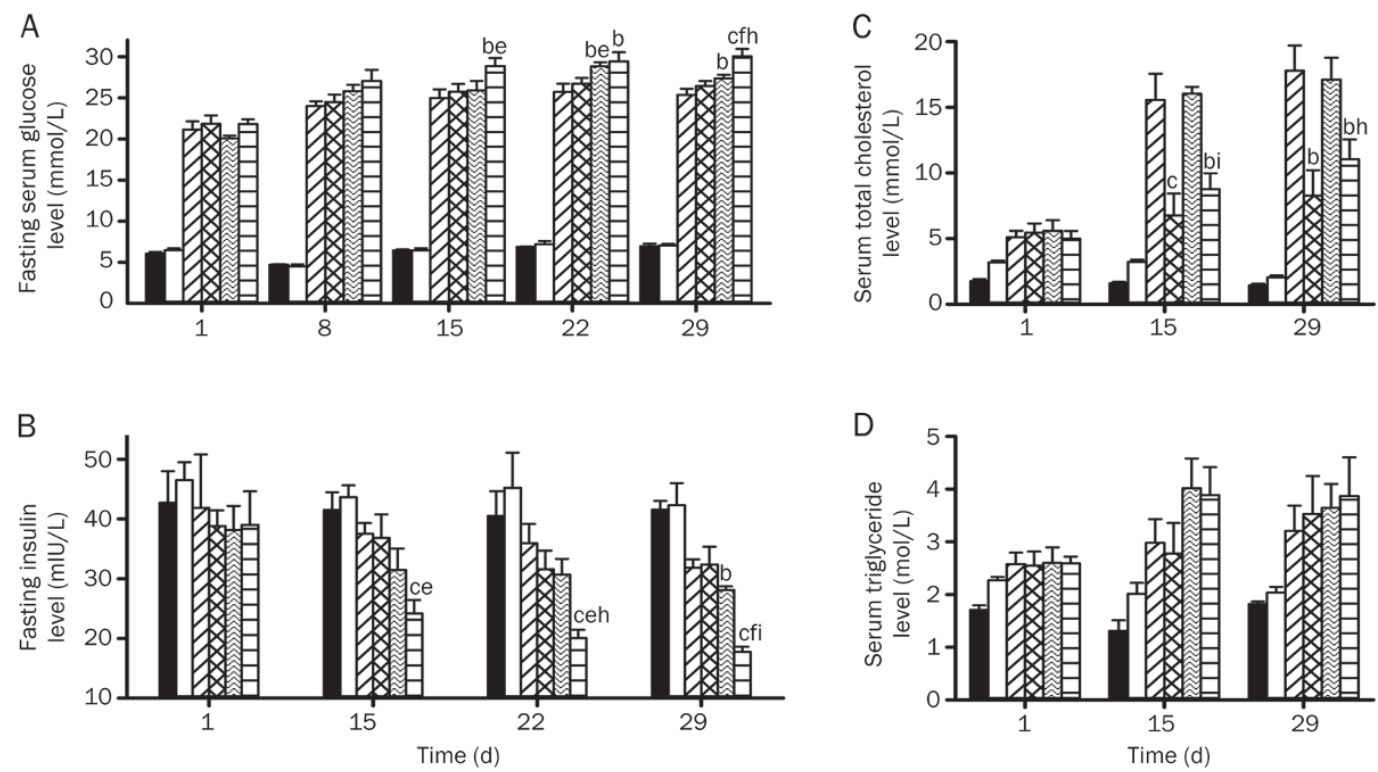

Figure 1. Effects of pravastatin, paroxetine and their comedication on the levels of fasting serum glucose (A), insulin (B), total cholesterol (C) and triglyceride $(D)$ in rats during the treatments. Symbols represent CON (black-bar), HFD (white bar), DM (diagonally-striped-bar), DM-PR (cross-hatched-bar), DM-PA (zigzag-striped-bars) and DM-CO (horizontally-striped-bar). Data represent the mean \pm SEM of $4-6$ rats. ${ }^{b} P<0.05,{ }^{c} P<0.01$ vs DM rats. ${ }^{e} P<0.05$, ${ }^{\mathrm{f}} P<0.01$ vs DM-PR rats. ${ }^{\mathrm{h}} \mathrm{P}<0.05,{ }^{\mathrm{i}} P<0.01$ vs DM-PA rats. 
A
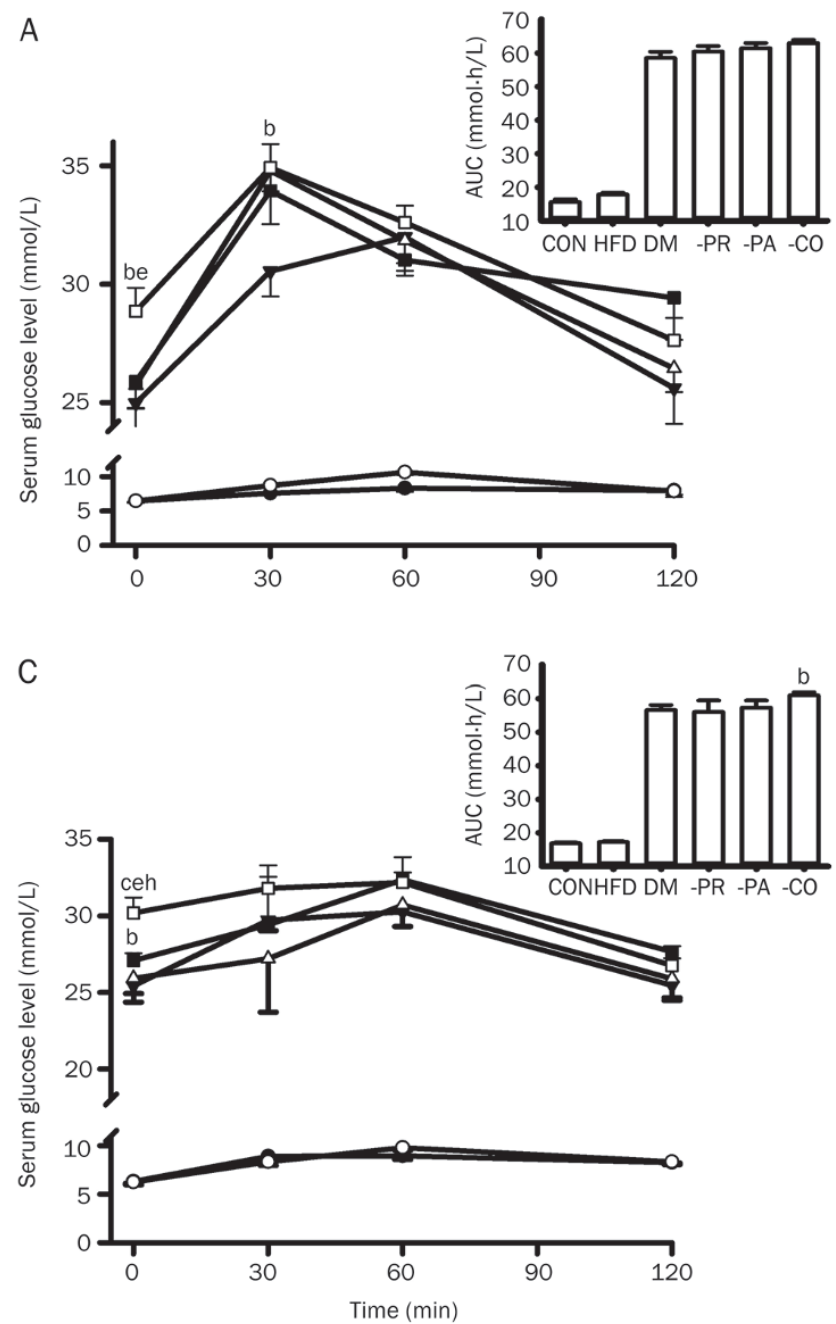

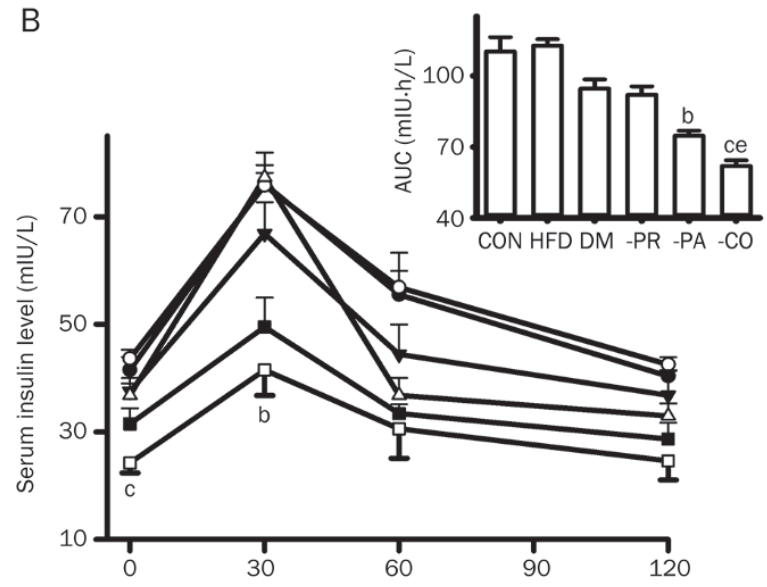

D

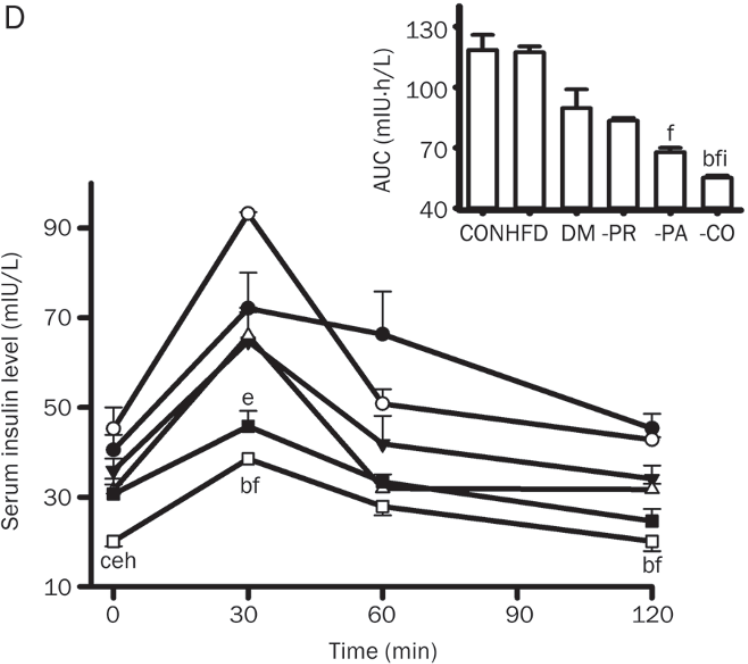

Figure 2. Effects of pravastatin, paroxetine and their comedication on postprandial glucose concentrations (A, C) and postprandial insulin concentrations (B, D) in rats after oral glucose loading ( $2 \mathrm{mg} / \mathrm{kg}$ ). (A and B) on d 15; (C and D) on d 28. Symbols represent CON (black circles), HFD (white circles), DM (black triangles), DM-PR (white triangles), DM-PA (black square) and DM-CO (white square). Data represent the mean \pm SEM of $4-6$ rats. ${ }^{\mathrm{b}} P<0.05,{ }^{\mathrm{c}} P<0.01$ vs DM rats. ${ }^{\mathrm{e}} P<0.05,{ }^{\mathrm{f}} P<0.01$ vs DM-PR rats. ${ }^{\mathrm{h}} P<0.05,{ }^{\mathrm{i}} P<0.01$ vs DM-PA rats.

Pharmacokinetics of paroxetine and pravastatin in DM rats after oral administration

The plasma concentrations of paroxetine and pravastatin in DM rats after oral administration on $\mathrm{d} 1$ and $\mathrm{d} 28$ were measured (Figure 4) and the corresponding pharmacokinetic parameters were estimated (Table 3). The results showed that, compared with DM-PA and DM-PR rats, DM-CO rats displayed the markedly increased plasma concentrations of both paroxetine and pravastatin, accompanied by the higher exposure (AUC and $C_{\max }$ values). Following a single dose (on d 1), the estimated $\mathrm{AUC}_{0-24}$ and $C_{\max }$ values for paroxetine in $\mathrm{DM}-\mathrm{CO}$ rats were $717.50 \pm 37.18 \mathrm{ng} \cdot \mathrm{h} / \mathrm{mL}$ and $129.16 \pm 18.55$ $\mathrm{ng} / \mathrm{mL}$, respectively, which were higher than those $\left(\mathrm{AUC}_{0-24}\right.$ : $529.78 \pm 55.28 \mathrm{ng} \cdot \mathrm{h} / \mathrm{mL}$ and $\left.C_{\max }: 63.56 \pm 7.28 \mathrm{ng} / \mathrm{mL}\right)$ in DM-PA rats (Figure $4 \mathrm{~A}$ and Table $3, P=0.0361$ for $\mathrm{AUC}_{0-24}$ and $P=0.0110$ for $\left.C_{\max }\right)$. Comedication also led to an increase in the $\mathrm{AUC}_{0-4}$ and $C_{\max }$ values for pravastatin by 3.51 -fold and 1.81 -fold relative to pravastatin alone (Figure $4 \mathrm{C}$ and Table $3, P=0.0001$ for
$\mathrm{AUC}_{0-4}$ and $P=0.0001$ for $C_{\text {max }}$ ).

Compared with the single dose (d 1), 28-d treatment with pravastatin and coadministration of paroxetine led to a decrease in the plasma concentration and total exposure to pravastatin (Figure 4D and Table 3). For example, the estimated $\mathrm{AUC}_{0-4}$ and $C_{\max }$ values for pravastatin on $\mathrm{d}$ 28 in DM-PR rats were $14.68 \pm 2.88 \mathrm{ng} \cdot \mathrm{h} / \mathrm{mL}$ and $8.38 \pm 1.68$ $\mathrm{ng} / \mathrm{mL}$, respectively, which were significantly lower than those $\left(\mathrm{AUC}_{0-4}: 26.94 \pm 1.31 \mathrm{ng} \cdot \mathrm{h} / \mathrm{mL}\right.$ and $C_{\max }: 31.85 \pm 4.64$ $\mathrm{ng} / \mathrm{mL})$ on $\mathrm{d} 1\left(P=0.0048\right.$ for $\mathrm{AUC}_{0-4}$ and $P=0.0014$ for $\left.C_{\max }\right)$. Similar to the finding on $\mathrm{d} 1$, comedication with paroxetine increased the $\mathrm{AUC}_{0-4}$ and $C_{\max }$ values for pravastatin, inducing increase by 1.9 -fold and 2.5-fold in DM-PR rats $(P=0.0044$ for $\mathrm{AUC}_{0-4}$ and $P=0.0002$ for $C_{\max }$ ). It was different from pravastatin in that a multi-dose of paroxetine did not affect the pharmacokinetic behavior of paroxetine (Figure 4B and Table 3). Coadministration of pravastatin also increased the exposure to paroxetine, leading to increases in the $\mathrm{AUC}_{0-24}$ and $C_{\max }$ 

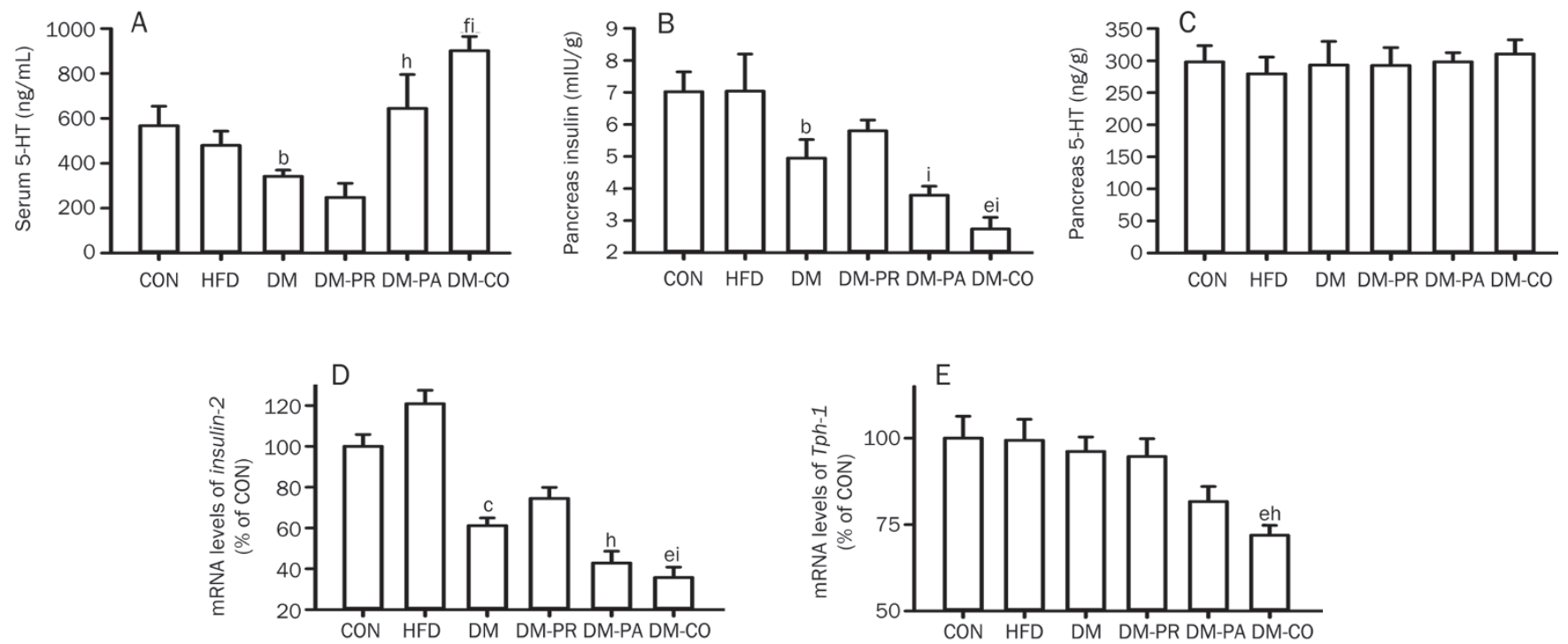

Figure 3. Effects of pravastatin, paroxetine and their comedication on the levels of serum 5-HT (A), pancreas insulin (B), pancreas 5-HT (C), Insulin-2 mRNA (D) and Tph-1 mRNA (E) of pancreas in rats after the treatments. Data represent the mean \pm SEM of 4 rats. ${ }^{\mathrm{b}} P<0.05$, ${ }^{\mathrm{c}} P<0.01 \mathrm{vs}$ CON rats. ${ }^{\mathrm{e}} P<0.05,{ }^{\mathrm{f}} P<0.01$ vs DM rats. ${ }^{\mathrm{h}} P<0.05,{ }^{\mathrm{i}} P<0.01$ vs DM-PR rats.

Table 3. Pharmacokinetic parameters of paroxetine and pravastatin after oral administration in diabetic rats on d 1 and 28 of treatment. Data represent the mean \pm SEM of $5-6$ rats. ${ }^{b} P<0.05,{ }^{c} P<0.01$ vs DM-PA or DM-PR on d $1 .{ }^{f} P<0.01$ vs DM-PA or DM-PR on d 28.

\begin{tabular}{|c|c|c|c|c|c|c|c|c|}
\hline & & $\begin{array}{l}t_{1 / 2} \\
\text { (h) }\end{array}$ & $\begin{array}{l}T_{\max } \\
\text { (h) }\end{array}$ & $\begin{array}{c}C_{\max } \\
(\mathrm{ng} / \mathrm{mL})\end{array}$ & $\begin{array}{c}\mathrm{AUC}_{0-\mathrm{t}} \\
(\mathrm{h} \cdot \mathrm{ng} / \mathrm{mL})\end{array}$ & $\begin{array}{c}\mathrm{AUC}_{0-\infty} \\
(\mathrm{h} \cdot \mathrm{ng} / \mathrm{mL})\end{array}$ & $\begin{array}{c}\mathrm{Cl} / \mathrm{F} \\
\left(\mathrm{L} \cdot \mathrm{h}^{-1} \cdot \mathrm{kg}^{-1}\right)\end{array}$ & $\begin{array}{l}\text { MRT } \\
\text { (h) }\end{array}$ \\
\hline \multicolumn{9}{|c|}{ Paroxetine } \\
\hline \multirow[t]{2}{*}{ d 1} & DM-PA & $3.21 \pm 0.34$ & $2.70 \pm 0.54$ & $63.56 \pm 7.28$ & $529.78 \pm 55.28$ & $535.35 \pm 56.44$ & $19.98 \pm 3.08$ & $6.49 \pm 0.21$ \\
\hline & DM-CO & $3.48 \pm 0.33$ & $2.40 \pm 0.40$ & $129.16 \pm 18.55^{b}$ & $717.50 \pm 37.18^{b}$ & $729.33 \pm 39.40^{b}$ & $14.58 \pm 0.97$ & $5.63 \pm 0.42$ \\
\hline d 28 & DM-PA & $3.94 \pm 0.25$ & $1.83 \pm 0.11$ & $73.95 \pm 10.02$ & $490.71 \pm 24.62$ & $514.75 \pm 33.47$ & $21.68 \pm 1.55$ & $6.64 \pm 0.26$ \\
\hline \multicolumn{9}{|c|}{ Pravastatin } \\
\hline \multirow[t]{2}{*}{ d 1} & DM-PR & $1.50 \pm 0.09$ & $0.25 \pm 0.00$ & $31.85 \pm 4.64$ & $26.94 \pm 1.31$ & $31.75 \pm 1.25$ & $317.02 \pm 13.13$ & $1.16 \pm 0.05$ \\
\hline & DM-CO & $0.93 \pm 0.19^{b}$ & $0.55 \pm 0.05^{c}$ & $89.56 \pm 5.00^{c}$ & $121.46 \pm 11.43^{c}$ & $128.83 \pm 10.28^{c}$ & $79.54 \pm 6.02^{c}$ & $1.23 \pm 0.04$ \\
\hline \multirow[t]{2}{*}{ d 28} & DM-PR & $1.95 \pm 0.24$ & $0.25 \pm 0.00$ & $8.38 \pm 1.68$ & $14.68 \pm 2.88$ & $18.96 \pm 3.01$ & $585.52 \pm 93.86$ & $1.50 \pm 0.05$ \\
\hline & DM-CO & $1.23 \pm 0.23$ & $0.55 \pm 0.05^{f}$ & $29.12 \pm 2.76^{f}$ & $43.05 \pm 6.65^{f}$ & $47.68 \pm 6.00^{f}$ & $222.56 \pm 25.55^{f}$ & $1.30 \pm 0.06$ \\
\hline
\end{tabular}

$\mathrm{AUC}_{0-\mathrm{t}}$ of paroxetine was $\mathrm{AUC}_{0-24}$ and $\mathrm{AUC}_{0-\mathrm{t}}$ of pravastatin was $\mathrm{AUC}_{0-4}$.

by $131.2 \%$ and $241.4 \%$ of DM-PA rats, separately $(P=0.0023$ for $\mathrm{AUC}_{0-24}$ and $P=0.0005$ for $\left.C_{\max }\right)$. The extent of increase in $\mathrm{AUC}_{0-24}$ by coadministration of pravastatin (by 1.3-fold) and $C_{\max }$ (by 2.4-fold) on d 28 of the dosing regimen were larger than those on $\mathrm{d} 1$ of the dosing regimen $\left(\mathrm{AUC}_{0-24}\right.$ by 0.4 -fold and $C_{\max }$ by 1.0 -fold).

\section{Effects of paroxetine and pravastatin on insulin secretion from INS-1 cells}

The present study clearly demonstrated that lower insulin levels in DM-CO rats were associated with higher exposure to paroxetine and pravastatin. To investigate whether the decreased insulin levels came from an increased exposure to paroxetine and pravastatin, the effects of paroxetine, pravastatin and their comedication on insulin secretion from INS-1 cells in the presence of $11.1 \mathrm{mmol} / \mathrm{L}$ and $2.8 \mathrm{mmol} / \mathrm{L}$ glucose were measured. The results showed that paroxetine inhibited the insulin secretion induced by glucose in a concentrationdependent manner (Figure 5A), accompanied by decreases in the intracellular insulin (Figure 5B) and 5-HT levels (Figure 5C). It was noticed that the inhibitory effect of paroxetine on insulin secretion was dependent on glucose levels. For example, insulin secretion from cells treated with $10 \mu \mathrm{mol} / \mathrm{L}$ paroxetine in presence of $11.1 \mathrm{mmol} / \mathrm{L}$ glucose was approximately $60 \%$ of control cells $(P=0.0136)$, while in the presence of $2.8 \mathrm{mmol} / \mathrm{L}$ glucose, the insulin secretion was only $30 \%$ of 

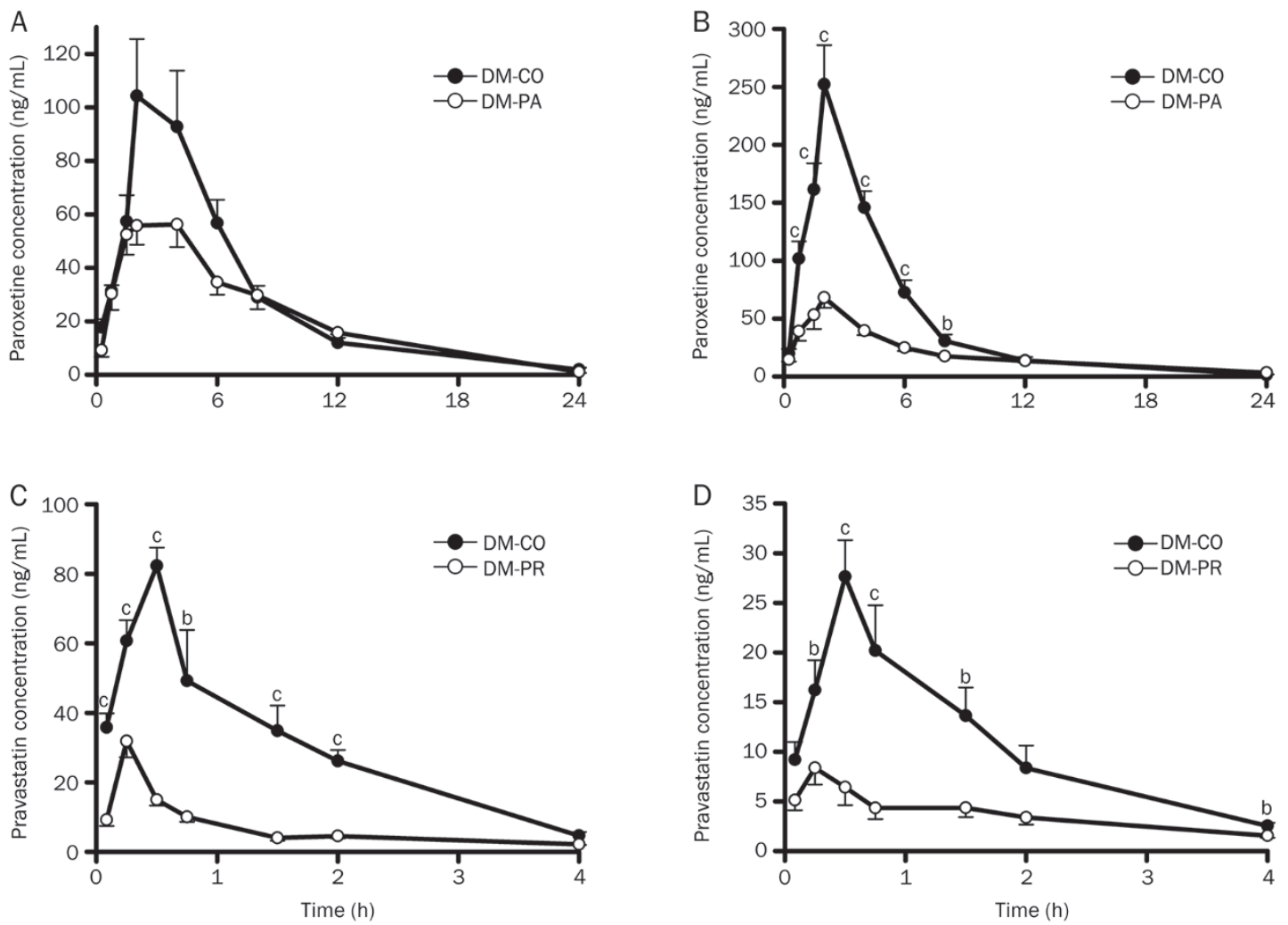

Figure 4. Plasma concentrations of paroxetine in DM-PA and DM-CO rats on $d 1(A)$ and $d 28$ (B); Plasma concentrations of pravastatin in DM-PR and DM-CO rats on $\mathrm{d} 1(\mathrm{C})$ and $\mathrm{d} 28$ (D). Data represent the mean \pm SEM of $5-6$ rats. ${ }^{\mathrm{b}} \mathrm{P}<0.05,{ }^{\mathrm{C}} \mathrm{P}<0.01$ vs DM-PR or DM-PA rats. PA: $10 \mathrm{mg} \cdot \mathrm{kg}^{-1} \cdot \mathrm{d}^{-1}$; PR: 10 $\mathrm{mg} \cdot \mathrm{kg}^{-1} \cdot \mathrm{d}^{-1}$.

control cells $(P=0.0001)$. On the contrary, pravastatin stimulated the insulin secretion (Figure 5D) induced by glucose, also in a concentration-dependent manner. The stimulatory effect of pravastatin on insulin secretion might be weakened by paroxetine (Figure 5E).

The effect of paroxetine on expression of Insulin-2 and Tph-1 mRNA in INS-1 cells was further documented. The results showed that paroxetine concentration-dependently suppressed expression of both Insulin-2 and Tph-1 mRNA (Figure $5 \mathrm{~F})$, which were parallel to the decreases in both insulin secretion and the levels of intracellular 5-HT.

\section{Effect of 5-HT on insulin secretion from INS-1 cells}

The effect of extracellular 5-HT on insulin secretion was further investigated. The results showed that extracellular 5-HT inhibited the insulin secretion from INS-1 cells in a concentration-dependent manner (Figure 6A) without affecting levels of intracellular 5-HT (Figure 6B), which indicated that the inhibitory effect, induced by $5-\mathrm{HT}$, on insulin secretion was not related to alterations in intracellular 5-HT.

Tropisetron, a $5-\mathrm{HT}_{3}$ receptor antagonist, was found to reverse the inhibition of insulin secretion by 5 - HT but itself did not affect insulin secretion. However, tropisetron did not affect paroxetine-induced inhibition of insulin secretion (Figure 6C).
Paroxetine metabolism in rat hepatic microsomes of experimental rats

Paroxetine was mainly metabolized in liver by CYP2D6. Paroxetine metabolism was investigated in rat hepatic microsomes of experimental rats and the clearance of paroxetine in hepatic microsomes $\left(\mathrm{Cl}_{\text {app, h }}\right)$ was estimated (Figure $7 \mathrm{~A}$ and 7B). The results showed that DM slightly increased paroxetine metabolism. Although pravastatin, paroxetine or coadministration of paroxetine and pravastatin all enhanced the increase in paroxetine metabolism induced by DM, the extent of increase by paroxetine or coadministration of paroxetine and pravastatin was less than that by pravastatin treatment. Data from QT-PCR showed that DM significantly induced expression of Cyp2D1 and Cyp2D2 mRNA ( $P=0.0001$ and 0.0492, respectively) compared with $\mathrm{CON}$ rats and that pravastatin treatment tended to further promote the expression of Cyp2D1 and Cyp2D2 mRNA induced by DM (Figure 7H).

A coincubation experiment showed that the inhibitory effect of pravastatin on paroxetine metabolism was very weak (Figure 7C). However, the inhibitory effect of pravastatin on paroxetine metabolism was markedly enhanced when pre-incubated with a NADPH-generation mixture and microsomes. Further study showed that the inhibition was dependent on $\mathrm{NADPH}$, pre-incubation time and pravastatin concentration, which was used to identify the mechanism-based inhibition. 

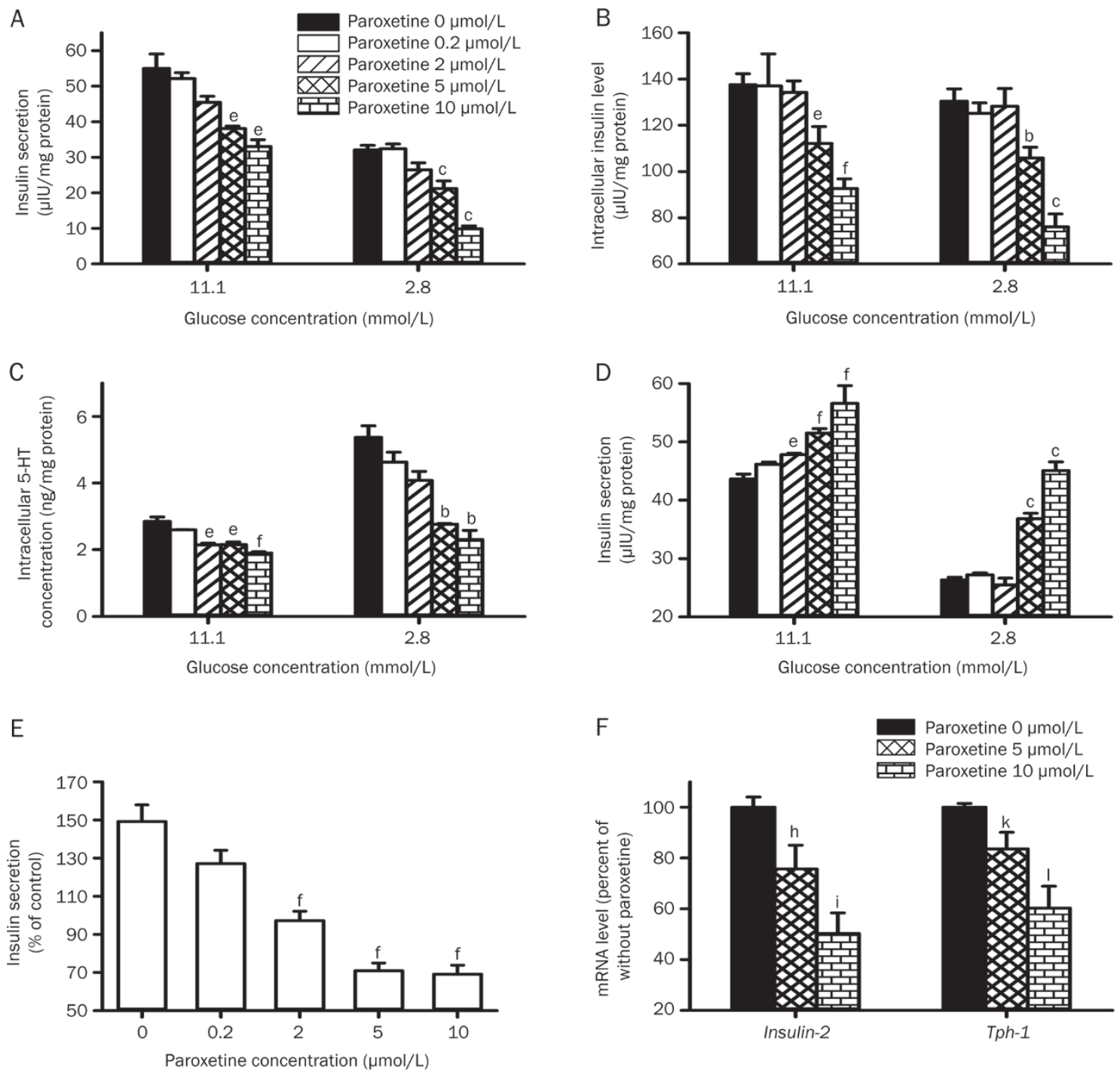

Figure 5. Effects of paroxetine on insulin secretion (A), intracellular insulin level (B) and intracellular 5-HT level (C) in INS-1 cells. Effects of pravastatin on insulin secretion (D) and the reversing effect of paroxetine on the stimulatory effect of $10 \mu \mathrm{mol} / \mathrm{L}$ pravastatin on insulin secretion in INS-1 cells (E). Effects of paroxetine on the levels of Insulin-2 and Tph-1 mRNA in INS-1cells (F). Data represent the mean \pm SEM of $3-4$. ${ }^{b} P<0.05,{ }^{c} P<0.01$ vs control with $2.8 \mathrm{mmol} / \mathrm{L}$ glucose; ${ }^{\mathrm{e}} P<0.05,{ }^{\mathrm{f}} P<0.01$ vs control with $11.1 \mathrm{mmol} / \mathrm{L}$ glucose. ${ }^{\mathrm{h}} P<0.05,{ }^{\mathrm{i}} P<0.01$ vs the Insulin-2 mRNA levels of that without paroxetine. ${ }^{\mathrm{k}} P<0.05,{ }^{\prime} P<0.01$ vs the Tph-1 mRNA levels of that without paroxetine.

\section{Pravastatin and paroxetine uptakes by hepatocytes}

Uptake of paroxetine by hepatocytes was documented. The results showed that pravastatin reduced the uptake of paroxetine by hepatocytes in a concentration-dependent manner (Figure 7D). Significant inhibition occurred following a 2-min incubation in the presence of pravastatin $(5$ and $25 \mu \mathrm{mol} / \mathrm{L}$, $P=0.0027$ and 0.0008 , respectively), at which time the uptake of paroxetine was only $78 \%$ and $66 \%$ of control cells, respectively. Paroxetine metabolism in primary cultured hepatocytes was also studied. It was observed that pravastatin inhibited paroxetine metabolism in a concentration-dependent manner (Figure 7E and 7F). Further study showed that the inhibitory effect of pravastatin on paroxetine metabolism in the hepatocytes was markedly stronger than that in the hepatic microsomes.
The effect of paroxetine on the uptake of pravastatin by hepatocytes was also investigated. Rifampicin, a typical inhibitor of Oatp2, served as positive control. The results showed that paroxetine inhibited pravastatin uptake by hepatocytes in a concentration-dependent manner (Figure 7G). Rifampicin also showed a similar inhibitory effect. Data from QT-PCR showed that DM up-regulated expression of Oatp 2 mRNA and pravastatin treatment strengthened the up-regulation of Oatp2 mRNA by DM (Figure 7H). In contrast, paroxetine treatment reversed the up-regulated expression of Oatp2 mRNA by DM, while coadministration of pravastatin partly reversed the decrease in Oatp2 mRNA expression by paroxetine.

\section{Discussion}

Both depression and hypercholesterolemia often accompany 
A

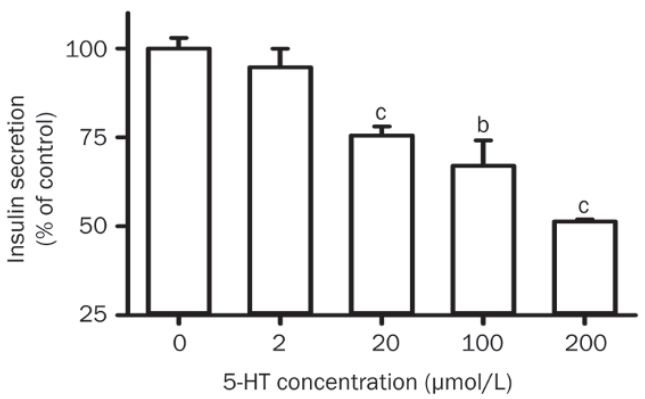

B
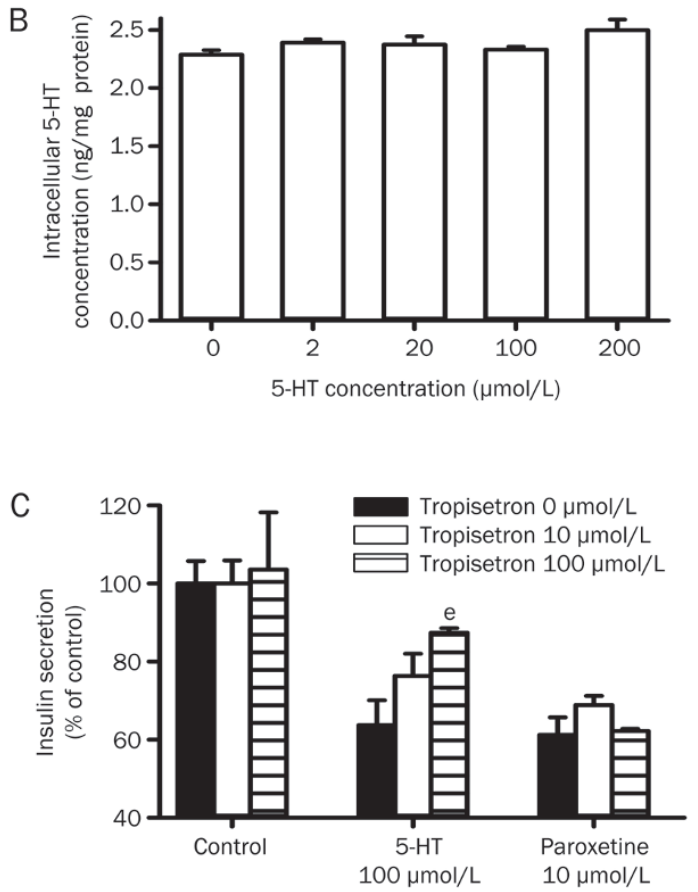

Figure 6. Effects of 5-HT on the insulin secretion (A) and intracellular 5-HT level (B) in INS-1 cells. Effects of tropisetron on 5-HT-induced and paroxetine-induced inhibition of insulin secretion of INS-1 cells (C). Data represent the mean \pm SEM of $3-4 .{ }^{b} P<0.05,{ }^{c} P<0.01$ vs control with 11.1 $\mathrm{mmol} / \mathrm{L}$ glucose. ${ }^{e} P<0.05$ vs $5-\mathrm{HT} 100 \mu \mathrm{mol} / \mathrm{L}$ without tropisetron.

diabetes. Thus, it is possible that the hypolipidemic agent pravastatin and the antidepressant paroxetine, the most widely prescribed drugs, are comedicated in diabetic patients. The aim of the present study was to verify the deregulation of glucose homeostasis by coadministration of paroxetine and pravastatin in diabetic rats and to identify the possible mechanisms via pharmacokinetic analysis. The diabetic rats were developed using the combination of HFD and low dose of STZ. The developed diabetic rats exhibited high levels of glucose and HOMA-IR. In addition, the rats also displayed abnormalities in lipid metabolism such as high triglyceride and cholesterol levels. All the syndromes were similar to those observed in diabetes patients, indicating that the induced rat diabetes model could reflect the natural history and metabolic characteristics of human diabetes.

The main finding of this study was that although paroxetine itself produced a trend toward impaired glycemic control and insulin secretion in diabetic rats, comedication with paroxetine and pravastatin further deteriorated glucose homeostasis, which was in accordance with clinical reports ${ }^{[14-16]}$. Compared with the DM rats, the DM-CO rats displayed lower insulin levels in both the serum and pancreas, which was in line with a decrease in the expression of pancreatic Insulin-2 mRNA, inferring that insulin biosynthesis was inhibited. Pharmacokinetic data showed that comedication with pravastatin and paroxetine increased exposure to both pravastatin and paroxetine. The increased exposure to pravastatin or paroxetine was inversely correlated with the levels of insulin in the serum and pancreas, inferring that the worsened glucose homeostasis in DM-CO rats resulted from increased exposure to pravastatin or paroxetine. Though pravastatin could prevent the onset of diabetes, our results showed that pravastatin had no effect on the fasting serum glucose and postprandial glucose levels in diabetic rats, which was consistent with prior reports ${ }^{[3,35,36]}$.

To verify above deduction, the effects of pravastatin, paroxetine and their comedication on insulin secretion from INS-1 cells were investigated. The results demonstrated that paroxetine concentration-dependently inhibited glucose-induced insulin secretion. In contrast, pravastatin stimulated insulin secretion from INS-1 cells in a concentration-dependent manner. The uptake of pravastatin into $\beta$-cells via Oatp2 might contribute to insulin secretion ${ }^{[5]}$, but our results indicate that paroxetine can inhibit the uptake of pravastatin via Oatp2 in liver. Therefore, paroxetine might also inhibit the uptake of pravastatin into $\beta$-cells via Oatp2 and thus weaken the stimulatory effect of pravastatin on insulin secretion. These findings excluded a role for pravastatin in the impairment of insulin secretion in DM-CO rats and allowed us to conclude that impairment of insulin secretion in DM-CO rats mainly came from the increased exposure to paroxetine. Data from QTPCR also clearly demonstrated that paroxetine reduced the expression of Insulin-2 mRNA in both INS-1 cells and the pancreas, leading to the inference that paroxetine inhibits insulin biosynthesis or insulin secretion via impairing the expression of Insulin-2 mRNA.

$5-\mathrm{HT}$, a marker of oscillatory insulin secretion ${ }^{[29]}$, is synthesized within $\beta$-cells and stored together with insulin in the secretory $\beta$-granules. Intracellular 5 -HT regulates insulin secretion via serotonylating GTPases including Rab3a and Rab27a, which induces co-release of 5-HT and insulin ${ }^{[37]}$. The present findings showed that the decreased insulin secretion by paroxetine was associated with a decrease in intracellular 5-HT levels, indicating that the lowered intracellular 5-HT levels may be another reason for the inhibitory effects of paroxetine on insulin secretion.

Intracellular 5-HT homeostasis is controlled by 5-HT biosynthesis via Tph-1 and reuptake through the serotonin reuptake transporter (SERT). Both in vivo and in vitro findings showed that paroxetine suppressed expression of Tph-1 mRNA. A prior report also showed that $T p h-1^{-1 /-1}$ mice were diabetic and had impaired insulin secretion due to the lack of 5-HT in the pancreas ${ }^{[37]}$. Our results showed that lowering intracellular 
A
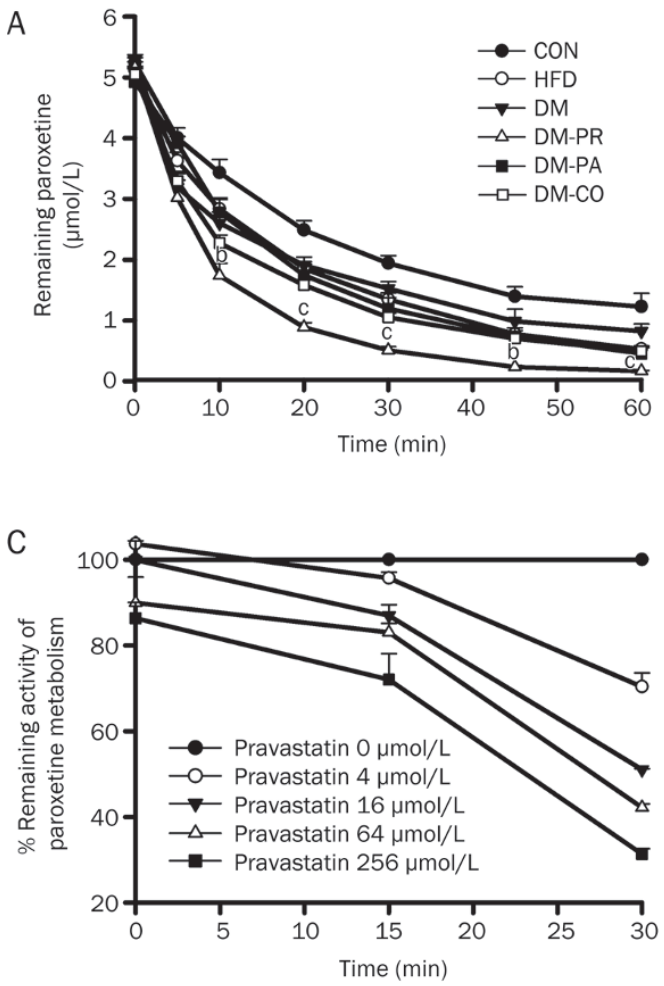

E
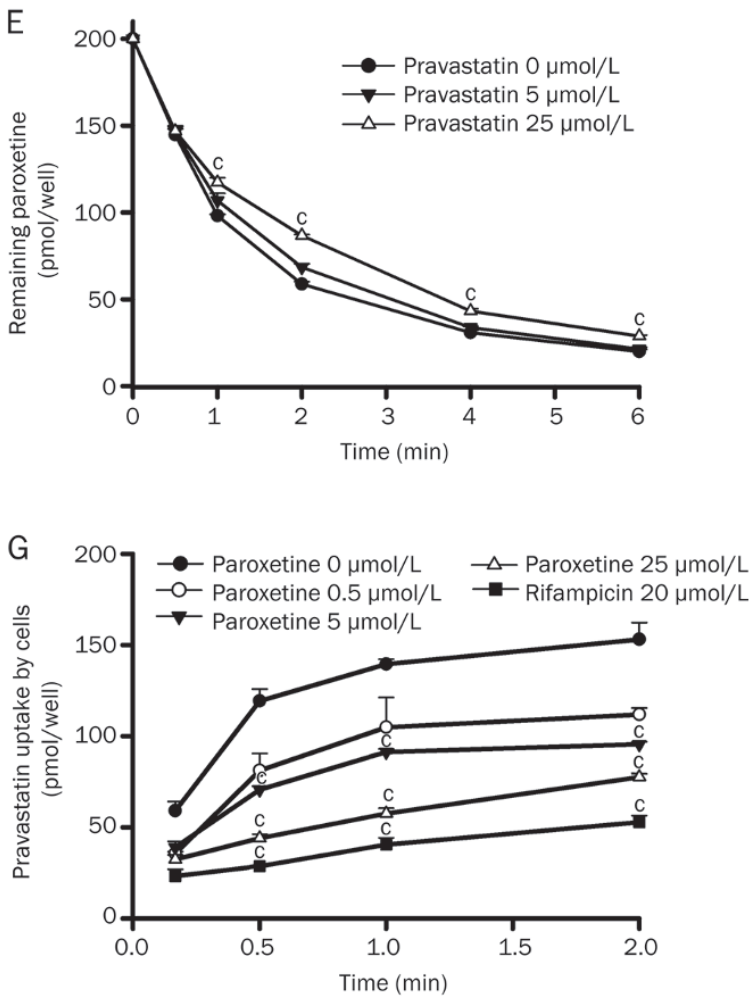

B
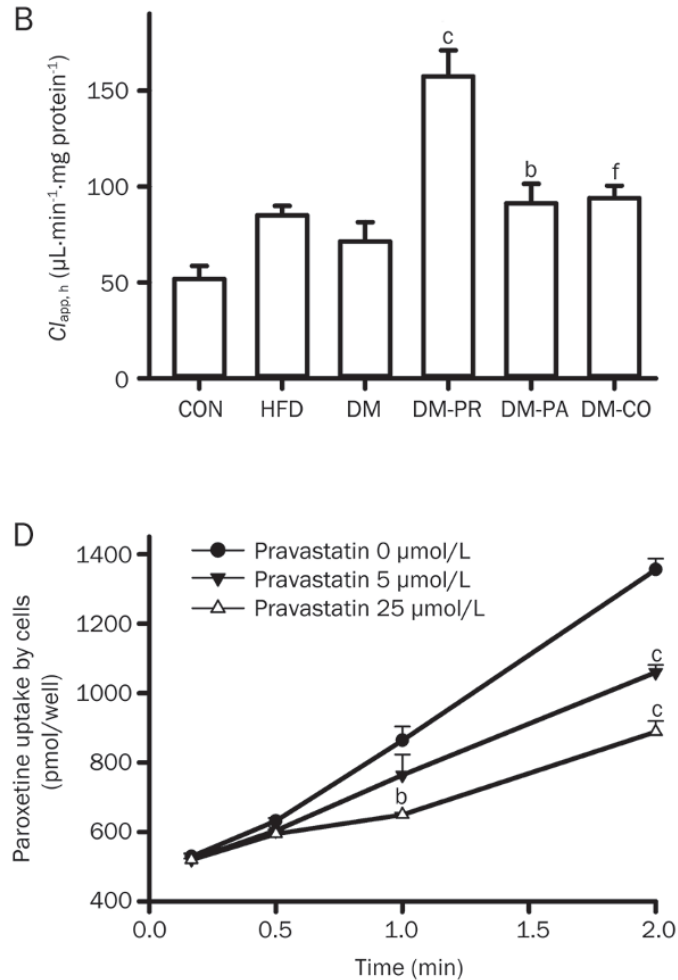

$\mathrm{F}$

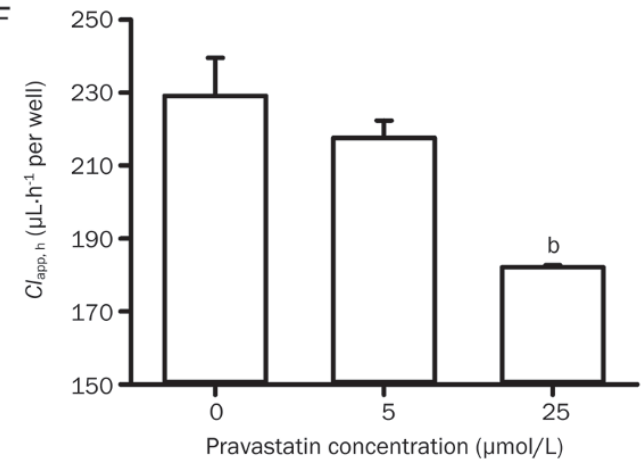

$\mathrm{H}$

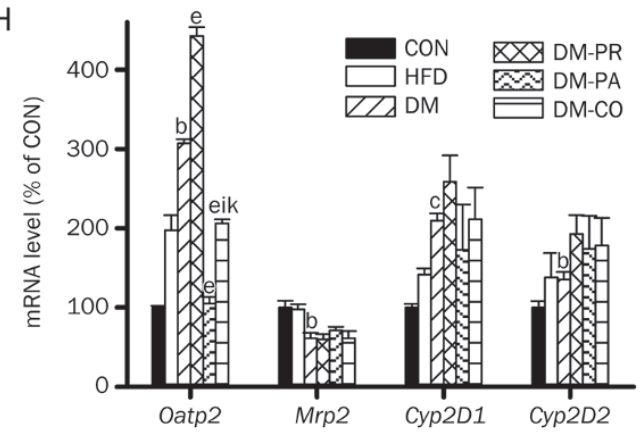

Figure 7. (A) Paroxetine metabolism (5 $\mathrm{\mu mol} / \mathrm{L})$ in hepatic microsomes of rats and (B) corresponding paroxetine clearance parameters in hepatic microsomes $\left(\mathrm{Cl}_{\text {app, h }}\right)$. ${ }^{\mathrm{b}} \mathrm{P}<0.05,{ }^{\mathrm{c}} \mathrm{P}<0.01$ vs DM rats. ${ }^{\mathrm{f}} \mathrm{P}<0.01$ vs DM-PR rats. (C) The time- and concentration-dependent inhibitory effect of pravastatin on paroxetine metabolism in diabetic rat hepatic microsomes. (D) The inhibitory effect of pravastatin on the uptake of paroxetine by hepatocytes. (E and $F$ ) Effects of pravastatin on the depletion of paroxetine $(0.2 \mu \mathrm{mol} / \mathrm{L})$ by hepatocytes and corresponding paroxetine clearance parameters in hepatocytes. (G) The inhibitory effect of paroxetine on the uptake of pravastatin in hepatocytes. Data represent the mean \pm SEM of $3-4 .{ }^{b} P<0.05,{ }^{\mathrm{c}} P<0.01 \mathrm{vs}$ control. $(\mathrm{H})$ Effects of paroxetine, pravastatin and their comedication on the expression of target gene mRNA of rats after $28 \mathrm{~d}$ treatment. ${ }^{\mathrm{b}} P<0.05$, ${ }^{\mathrm{c}} P<0.01 \mathrm{vs}$ CON rats. ${ }^{e} P<0.05$ vs DM rats. ${ }^{i} P<0.01$ vs DM-PR rats. ${ }^{k} P<0.05$ vs DM-PA rats. 
5-HT levels by paroxetine was associated with the suppressed expression of Tph-1 mRNA, indicating that the paroxetineinduced decrease in intracellular 5-HT levels was partly attributed to inhibition of Tph-1 mRNA expression.

Proper action of the insulin receptor substrate (IRS) proteins is considered to be essential for $\beta$-cell function and insulin secretion. SSRIs sertraline and paroxetine were reported to inhibit insulin-induced Tyr phosphorylation of the IRS-2 protein and the activation of its downstream targets Akt and S6K1. Suppression of $\beta$-cell function by sertraline was involved in inhibiting the increase in cellular reducing power stimulated by glucose, activating endoplasmic reticulum stress, triggering the unfolded protein response and inducing $\beta$-cell apoptosis ${ }^{[38]}$. In addition, the expression and function of SERT were reported to be associated with insulin secretion $^{[39,40]}$. All these findings may explain why paroxetine inhibits insulin secretion, and they need to be further verified.

The SERT is highly abundant in the cell membranes of peripheral tissues and neuronal synapses, and 5-HT is mainly stored in enterochromaffin cells and platelets ${ }^{[41]}$. Paroxetine increased serum 5-HT levels through inhibiting the reuptake of 5 -HT by these cells. Several reports have demonstrated that 5 -HT affects insulin secretion via 5 -HT receptors ${ }^{[30,42,43]}$. Our study showed that unlike intracellular 5-HT, extracellular 5-HT inhibited rather than stimulated insulin secretion, which was in an agreement with previous reports ${ }^{[37]}$. The inhibition of insulin secretion by 5-HT may be reversed by the $5-\mathrm{HT}_{3}$ receptor antagonist tropisetron, inferring a role for the $5-\mathrm{HT}_{3}$ receptor in 5-HT-induced insulin secretion. However, tropisetron did not affect the inhibition of insulin secretion by paroxetine, indicating that the inhibitory effect of paroxetine on insulin secretion did not involve extracellular 5-HT.

The present study clearly demonstrated that the exposure to both paroxetine and pravastatin in plasma were increased when these compounds were comedicated. The mechanisms leading to the increased exposure were investigated using hepatic microsomes and freshly isolated hepatocytes from experimental rats. In contrast to our expectation, compared with DM rats, paroxetine metabolism in hepatic microsomes from DM-PR rats was enhanced rather than decreased, and paroxetine metabolism in hepatic microsomes from DM-PA rats was similar to that in DM-CO rats. It was generally accepted that paroxetine is mainly metabolized by CYP2D6 and human CYP2D6 is equivalent to Cyp2D1 and Cyp2D2 in rats. Therefore, levels of Cyp2D1 and Cyp2D2 mRNA were measured. Data from QT-PCR demonstrated that pravastatin increased the levels of Cyp2D1 mRNA, which was in line with an increase in paroxetine metabolism in hepatic microsomes, indicating that the pravastatin-induced increased exposure to paroxetine did not come from an alteration in the levels of Cyp2D1 mRNA.

Pravastatin was reported to inhibit CYP2D6 activity ${ }^{[21,22]}$. Inhibition experiments showed that although the reversible inhibitory effects of pravastatin on paroxetine metabolism in hepatic microsomes were weak, the inhibitory effects were enhanced by pre-incubation with a NADPH-generation mix- ture, indicating a mechanistic link. Pravastatin inhibited paroxetine uptake and metabolism by freshly isolated hepatocytes. The inhibitory effects of pravastatin on paroxetine metabolism in hepatocytes was markedly stronger than that in hepatic microsomes, indicating that the inhibition of paroxetine uptake by hepatocytes could be the main reason that coadministration of pravastatin increased the exposure to paroxetine. Of course, other factors including the direct inhibitory effect of pravastatin on paroxetine metabolism were not excluded.

Uptake of pravastatin by Oatp2 in hepatocytes is considered to be a rate-determining process in its hepatic clearance via Oatp $2^{[44]}$. Levels of hepatic Oatp2 mRNA were measured. Consistent with previous report ${ }^{[45]}$, DM increased the level of Oatp 2 mRNA. Pravastatin treatment further enhanced the DM-induced increase in Oatp2 mRNA levels, but the up-regulation of Oatp 2 mRNA by pravastatin could be reversed by coadministration of paroxetine. Our in vitro study showed that paroxetine inhibited the uptake of pravastatin by hepatocytes in a concentration-dependent manner, indicating that paroxetine increased exposure to pravastatin via inhibiting expression of Oatp2 mRNA and inhibiting the uptake of pravastatin by hepatocytes. The fact that expression of Oatp 2 mRNA was induced by pravastatin might partly explain the finding that the plasma concentration of and exposure to pravastatin on d 28 of the dosing regimen were lower than those measured on $\mathrm{d} 1$. It was generally accepted that pravastatin inhibited cholesterol synthesis within the liver. Our results showed that coadministration of paroxetine markedly decreased the hepatic uptake of pravastatin (Figure 7G), which may become a reason that paroxetine weakened the cholesterol-lowering effects of pravastatin (Figure 1C). Although the transport of pravastatin from the blood into the bile is mainly mediated by Mrp2 ${ }^{[46,47]}$, data from QT-PCR showed that drug treatment did not disrupt the effects of DM on Mrp2 mRNA levels, excluding the possibility that Mrp2 mRNA levels might explain the increased exposure to pravastatin by coadministration of paroxetine.

STZ could cause diabetes, but the half-life of STZ is in minutes $^{[48]}$, so that there would be no residual STZ or its metabolites in the rats when our treatments began at $7 \mathrm{~d}$ following STZ-injection. Therefore, it is unlikely that STZ directly interfered with the pharmacokinetics of paroxetine or pravastatin, or the reverse. However, the mechanism underlying the pharmacokinetics interaction between paroxetine and pravastatin requires further study.

Long-term administration of paroxetine alone also tended to increase the serum glucose levels and decrease serum insulin. So, in high-dose or long-term paroxetine medication regimen, the serum glucose levels should also be measured. Our results showed that the high glucose levels attributed to pravastatin altered the pharmacokinetics of paroxetine. Therefore, in the clinic, the dose could be adjusted to avoid adverse effects with the prerequisite of ensuring efficacy.

In conclusion, the present study verified that comedication with paroxetine and pravastatin worsened glycemic control 
and insulin secretion in diabetic rats, which was attributed to an increased plasma concentration of and exposure to paroxetine. Paroxetine inhibited insulin secretion via decreasing intracellular 5-HT and insulin biosynthesis resulted from suppression of Tph-1 and Insulin-2 mRNA. The potential drug-drug interaction between paroxetine and pravastatin on glucose homeostasis in the clinic should be monitored in diabetic patients. Further studies are needed to clarify the clinical significance of comedication with paroxetine and pravastatin in diabetic patients.

\section{Acknowledgements}

This work was supported by funding from the Graduate Student Research and Innovation Program of Jiangsu Province (No CXZZ12 0325, 2012) and funding for National Natural Science Foundation of China (No 81373482), National Youth Science Foundation of China (№ 81102503), and the Fundamental Research Funds for the Central Universities (ZD2014YX0026).

\section{Author contribution}

Feng LI and Xiao-dong LIU designed and performed research, analyzed data, and wrote the manuscript; Mian ZHANG, Dan $\mathrm{XU}$, and Can LIU performed research and reviewed the manuscript; Ze-yu ZHONG, Ling-ling JIA, Meng-yue HU, and Yang YANG performed research and analyzed data; and Li LIU reviewed and edited the manuscript.

\section{Abbreviations}

CON rats, normal control rat; DM, diabetes; DM-PR rats, diabetic rats treated with pravastatin; DM-PA rats, diabetic rats treated with paroxetine; DM-CO rats, diabetic rats comedicated with paroxetine and pravastatin; HFD rats, rats fed with high fat diet; 5-HT, serotonin; INS-1 cells, insulin-secreting cell line; Mrp2, multidrug resistance-associated protein 2; Oatp, organic anion transporter polypeptides transporter; QT-PCR, quantitative real-time PCR; SSRIs, selective serotonin reuptake inhibitors; STZ, streptozotocin; Tph-1, tryptophan hydroxylase-1.

\section{References}

1 Colhoun HM, Betteridge DJ, Durrington PN, Hitman GA, Neil HA, Livingstone SJ, et al. Primary prevention of cardiovascular disease with atorvastatin in type 2 diabetes in the Collaborative Atorvastatin Diabetes Study (CARDS): multicentre randomised placebo-controlled trial. Lancet 2004; 364: 685-96.

2 Guclu F, Ozmen B, Hekimsoy Z, Kirmaz C. Effects of a statin group drug, pravastatin, on the insulin resistance in patients with metabolic syndrome. Biomed Pharmacother 2004; 58: 614-8.

3 Araki K, Masaki T, Katsuragi I, Kakuma T, Yoshimatsu H. Effects of pravastatin on obesity, diabetes, and adiponectin in diet-induced obese mice. Obesity (Silver Spring) 2008; 16: 2068-73.

4 Freeman DJ, Norrie J, Sattar N, Neely RD, Cobbe SM, Ford I, et al. Pravastatin and the development of diabetes mellitus: evidence for a protective treatment effect in the West of Scotland Coronary Prevention Study. Circulation 2001; 103: 357-62.

5 Abe M, Toyohara T, Ishii A, Suzuki T, Noguchi N, Akiyama Y, et al. The
HMG-CoA reductase inhibitor pravastatin stimulates insulin secretion through organic anion transporter polypeptides. Drug Metab Pharmacokinet 2010; 25: 274-82.

6 Madhu M1, Abish A, Anu K, Jophin RI, Kiran AM, Vijayakumar K. Predictors of depression among patients with diabetes mellitus in Southern India. Asian J Psychiatr 2013; 6: 313-7.

7 Zuberi SI, Syed EU, Bhatti JA. Association of depression with treatment outcomes in type 2 diabetes mellitus: a cross-sectional study from Karachi, Pakistan. BMC Psychiatry 2011; 11: 27.

8 Gentili P, Maldonato A, Scalabrino AM. The influence of psychological factors on the patient's management of diabetes. Critical survey of psychodynamic models on personal management of diabetes. Minerva Psichiatr 1996; 37: 83-90.

9 Lustman PJ, Griffith LS, Clouse RE, Cryer PE. Psychiatric illness in diabetes mellitus. Relationship to symptoms and glucose control. J Nerv Ment Dis 1986; 174: 736-42.

10 Paile-Hyvarinen M, Wahlbeck K, Eriksson JG. Quality of life and metabolic status in mildly depressed women with type 2 diabetes treated with paroxetine: a single-blind randomised placebo controlled trial. BMC Fam Pract 2003; 4 : 7.

11 Gulseren L, Gulseren S, Hekimsoy Z, Mete L. Comparison of fluoxetine and paroxetine in type II diabetes mellitus patients. Arch Med Res 2005; 36: 159-65.

12 Derijks HJ, Meyboom RH, Heerdink ER, De Koning FH, Janknegt R, Lindquist $\mathrm{M}$, et al. The association between antidepressant use and disturbances in glucose homeostasis: evidence from spontaneous reports. Eur J Clin Pharmacol 2008; 64: 531-8.

13 Yoon JM, Cho EG, Lee HK, Park SM. Antidepressant use and diabetes mellitus risk: a meta-analysis. Korean J Fam Med 2013; 34: 228-40.

14 Tatonetti NP, Denny JC, Murphy SN, Fernald GH, Krishnan G, Castro $\mathrm{V}$, et al. Detecting drug interactions from adverse-event reports: interaction between paroxetine and pravastatin increases blood glucose levels. Clin Pharmacol Ther 2011; 90: 133-42.

15 White RW, Tatonetti NP, Shah NH, Altman RB, Horvitz E. Web-scale pharmacovigilance: listening to signals from the crowd. J Am Med Inform Assoc 2013; 20: 404-8.

16 An L, Ravindran PP, Renukunta S, Denduluri S. Co-medication of pravastatin and paroxetine-a categorical study. J Clin Pharmacol 2013; doi: 10.1002/jcph.151.

17 Bourin M, Chue P, Guillon Y. Paroxetine: a review. CNS Drug Rev 2001; 7: 25-47.

18 Komai T, Kawai K, Tokui T, Tokui Y, Kuroiwa C, Shigehara E, et al. Disposition and metabolism of pravastatin sodium in rats, dogs and monkeys. Eur J Drug Metab Pharmacokinet 1992; 17: 103-13.

19 Schachter M. Chemical, pharmacokinetic and pharmacodynamic properties of statins: an update. Fundam Clin Pharmacol 2005; 19: 117-25.

20 Kalliokoski A, Niemi M. Impact of OATP transporters on pharmacokinetics. Br J Pharmacol 2009; 158: 693-705.

21 Transon C, Leemann T, Dayer P. In vitro comparative inhibition profiles of major human drug metabolising cytochrome P450 isozymes (CYP2C9, CYP2D6, and CYP3A4) by HMG-CoA reductase inhibitors. Eur J Clin Pharmacol 1996; 50: 209-15.

22 Hatanaka T. Clinical pharmacokinetics of pravastatin: mechanisms of pharmacokinetic events. Clin Pharmacokinet 2000; 39: 397-412.

23 Chen GM, Hu N, Liu L, Xie SS, Wang P, Li J, et al. Pharmacokinetics of verapamil in diabetic rats induced by combination of high-fat diet and streptozotocin injection. Xenobiotica 2011; 41: 494-500.

24 Liu C, Zhang M, Hu MY, Guo HF, Li J, Yu YL, et al. Increased glucagonlike peptide-1 secretion may be involved in antidiabetic effects of ginsenosides. J Endocrinol 2013; 217: 185-96. 
25 Kobayashi T, Matsumoto T, Kamata K. Mechanisms underlying the chronic pravastatin treatment-induced improvement in the impaired endothelium-dependent aortic relaxation seen in streptozotocininduced diabetic rats. Br J Pharmacol 2000; 131: 231-8.

26 Besson A, Haddjeri N, Blier P, de Montigny C. Effects of the coadministration of mirtazapine and paroxetine on serotonergic neurotransmission in the rat brain. Eur Neuropsychopharmacol 2000; 10: 177-88.

27 Watanabe T, Kusuhara H, Maeda K, Shitara Y, Sugiyama Y. Physiologically based pharmacokinetic modeling to predict transportermediated clearance and distribution of pravastatin in humans. J Pharmacol Exp Ther 2009; 328: 652-62.

28 Shin JG, Kim KA, Yoon YR, Cha IJ, Kim YH, Shin SG. Rapid simple high-performance liquid chromatographic determination of paroxetine in human plasma. J Chromatogr B Biomed Sci Appl 1998; 713: 452-6.

29 Deeney JT, Branstrom R, Corkey BE, Larsson O, Berggren PO. ${ }^{3} \mathrm{H}$-serotonin as a marker of oscillatory insulin secretion in clonal betacells (INS-1). FEBS Lett 2007; 581: 4080-4.

30 Heimes K, Feistel B, Verspohl EJ. Impact of the $5-\mathrm{HT}_{3}$ receptor channel system for insulin secretion and interaction of ginger extracts. Eur J Pharmacol 2009; 624: 58-65.

31 Hu N, Xie S, Liu L, Wang X, Pan X, Chen G, et al. Opposite effect of diabetes mellitus induced by streptozotocin on oral and intravenous pharmacokinetics of verapamil in rats. Drug Metab Dispos 2010; 39 : 419-25.

32 Obach RS. Prediction of human clearance of twenty-nine drugs from hepatic microsomal intrinsic clearance data: An examination of in vitro half-life approach and nonspecific binding to microsomes. Drug Metab Dispos 1999; 27: 1350-9.

33 Komai T, Shigehara E, Tokui T, Koga T, Ishigami M, Kuroiwa C, et al. Carrier-mediated uptake of pravastatin by rat hepatocytes in primary culture. Biochem Pharmacol 1992; 43: 667-70.

34 Ishigami M, Tokui T, Komai T, Tsukahara K, Yamazaki M, Sugiyama Y. Evaluation of the uptake of pravastatin by perfused rat liver and primary cultured rat hepatocytes. Pharm Res 1995; 12: 1741-5.

35 Kanda M, Satoh K, Ichihara K. Effects of atorvastatin and pravastatin on glucose tolerance in diabetic rats mildly induced by streptozotocin. Biol Pharm Bull 2003; 26: 1681-4.

36 Satoh K, Keimatsu N, Kanda M, Kasai T, Takaguri A, Sun F, et al. HMG-CoA reductase inhibitors do not improve glucose intolerance in spontaneously diabetic Goto-Kakizaki rats. Biol Pharm Bull 2005; 28 :
2092-5.

37 Paulmann N, Grohmann M, Voigt JP, Bert B, Vowinckel J, Bader M, et al. Intracellular serotonin modulates insulin secretion from pancreatic beta-cells by protein serotonylation. PLoS Biol 2009; 7: e1000229.

38 Isaac R, Boura-Halfon S, Gurevitch D, Shainskaya A, Levkovitz Y, Zick Y. Selective serotonin reuptake inhibitors (SSRIs) inhibit insulin secretion and action in pancreatic beta cells. J Biol Chem 2013; 288: 5682-93.

39 Hoffman JB, Kaplan JR, Kinkead B, Berga SL, Wilson ME. Metabolic and reproductive consequences of the serotonin transporter promoter polymorphism (5-HTTLPR) in adult female rhesus monkeys (Macaca mulatta). Endocrine 2007; 31: 202-11.

40 Jarrell H, Hoffman JB, Kaplan JR, Berga S, Kinkead B, Wilson ME. Polymorphisms in the serotonin reuptake transporter gene modify the consequences of social status on metabolic health in female rhesus monkeys. Physiol Behav 2008; 93: 807-19.

41 Lam DD, Heisler LK. Serotonin and energy balance: molecular mechanisms and implications for type 2 diabetes. Expert Rev Mol Med 2007; 9: 1-24.

42 Gilles M, Wilke A, Kopf D, Nonell A, Lehnert H, Deuschle M. Antagonism of the serotonin (5-HT)-2 receptor and insulin sensitivity: implications for atypical antipsychotics. Psychosom Med 2005; 67: 748-51.

43 Zhang Q, Zhu Y, Zhou W, Gao L, Yuan L, Han X. Serotonin receptor 2C and insulin secretion. PLoS One 2013; 8: e54250.

44 Tokui T, Nakai D, Nakagomi R, Yawo H, Abe T, Sugiyama Y. Pravastatin, an HMG-CoA reductase inhibitor, is transported by rat organic anion transporting polypeptide, oatp2. Pharm Res 1999; 16: 904-8.

45 Hasegawa Y, Kishimoto S, Shibatani N, Inotsume N, Takeuchi Y, Fukushima S. The disposition of pravastatin in a rat model of streptozotocin-induced diabetes and organic anion transporting polypeptide 2 and multidrug resistance-associated protein 2 expression in the liver. Biol Pharm Bull 2010; 33: 153-6.

46 Ellis LC, Hawksworth GM, Weaver RJ. ATP-dependent transport of statins by human and rat MRP2/Mrp2. Toxicol Appl Pharmacol 2013; 269: 187-94.

47 Kivisto KT, Grisk O, Hofmann U, Meissner K, Moritz KU, Ritter C, et al. Disposition of oral and intravenous pravastatin in MRP2-deficient TRrats. Drug Metab Dispos 2005; 33: 1593-6.

48 Reynolds WA, Chez RA, Bhuyan BK, Neil GL. Placental transfer of streptozotocin in the rhesus monkey. Diabetes 1974; 23: 777-82. 